\title{
Complexation of Oxonium and Ammonium Ions by Lower-rim Calix[4]arene Amino Acid Derivatives ${ }^{\dagger}$
}

\author{
Josip Požar, ${ }^{\text {a }}$ Gordan Horvat, ${ }^{\text {a }}$ Marina Čalogović, ${ }^{\text {a }}$ Nives Galić, ${ }^{\mathrm{a}}$ \\ Leo Frkanec, ${ }^{\mathrm{b}}$ and Vladislav Tomišića ${ }^{\mathrm{a}, *}$ \\ ${ }^{\mathrm{a}}$ Department of Chemistry, Faculty of Science, University of Zagreb, Horvatovac 102a, HR-10000 Zagreb, Croatia
${ }^{\mathrm{b}}$ Department of Organic Chemistry and Biochemistry, Ruđer Bošković Institute, Bijenička c. 54, HR.10000 Zagreb, Croatia
}

RECEIVED OCTOBER 2, 2012; ACCEPTED NOVEMBER 28, 2012

\begin{abstract}
Complexation of oxonium and ammonium cations with two calix[4]arene amino acid derivatives, namely 5,11,17,23-tetra-tert-butyl-26,28,25,27-tetrakis-( $O$-methyl-D- $\alpha$-phenylglycylcarbonylmethoxy)calix[4]arene (1) and 5,11,17,23-tetra-tert-butyl-26,28,25,27-( $O$-methyl-L-leucylcarbonylmethoxy)calix[4]arene (2), in acetonitrile and methanol was studied by means of spectrophotometric and calorimetric titrations at $25^{\circ} \mathrm{C}$. The classical molecular dynamics simulations of the macrocycles and the corresponding complexes with $\mathrm{NH}_{4}{ }^{+}$and $\mathrm{H}_{3} \mathrm{O}^{+}$were carried out in order to investigate their possible structures in solution. The examined calix[4]arene derivatives were shown to be rather efficient binders for $\mathrm{H}_{3} \mathrm{O}^{+}$cation and moderately efficient for $\mathrm{NH}_{4}{ }^{+}$in acetonitrile, whereas the complexation of these cations in methanol could not be observed. The structures of the complexes obtained by means of molecular dynamics simulations suggested the involvement of ether and carbonyl oxygen atoms in the complexation of both $\mathrm{NH}_{4}{ }^{+}$ and $\mathrm{H}_{3} \mathrm{O}^{+}$. An inclusion of an acetonitrile molecule into the hydrophobic cavity of the free and complexed ligands was observed as well. The difference in binding affinities of $\mathbf{1}$ and $\mathbf{2}$ towards $\mathrm{NH}_{4}{ }^{+}$and $\mathrm{H}_{3} \mathrm{O}^{+}$ions could be explained by taking into account cation solvation, difference in their size and in the strength of hydrogen bonding between cations and the ligand binding sites. (doi: 10.5562/cca2172)
\end{abstract}

Keywords: calixarenes, oxonium cation, ammonium cation, complexation, solvation, microcalorimetry, UV spectrometry, molecular dynamics

\section{INTRODUCTION}

Calixarenes have been widely recognized as suitable parent compounds for the synthesis of efficient receptors of ions and neutral molecules. ${ }^{1-4}$ Their main advantages as host templates are the relatively simple synthesis and the possibility of both, lower- and upperrim functionalization. ${ }^{1,2}$ Additionally, by the appropriate choice of the introduced donor atoms and the number of the repeating phenolic units notable selectivity and high affinity towards variety of guests can be achieved. ${ }^{3-5}$ Among the numerous calixarenes investigated, a class of macrocycles functionalized with carbonyl-containing substituents at the lower rim, which include calixarene ketones, esters and amides, have been reported as effective receptors for alkali and alkaline-earth metal cations. $^{3,6,7}$ In general, calix[4]arene derivatives prefer smaller cations (e.g. $\mathrm{Li}^{+}$and $\mathrm{Na}^{+}$), whereas the larger metal ions $\left(e . g . \mathrm{Rb}^{+}, \mathrm{Cs}^{+}\right)$fit well into the hydrophilic cavities of calix[6]arenes. Apart from the cation size, the binding process is often strongly influenced by the solvation of the reactants and the complex formed ${ }^{8-10}$. In acetonitrile, the inclusion of a solvent molecule into the calixarene hydrophobic cavity ${ }^{10-17}$ was shown to be synergetic with the cation complexation. In the derivatives having substituents with secondary amide groups the presence of intramolecular $\mathrm{NH} \cdots \mathrm{O}=\mathrm{C}$ hydrogen bonds considerably reduces the ionophoric activity of macrocycles compared to tertiary amide derivatives. ${ }^{10,18-21}$

Interestingly, unlike the binding of alkali-metal cations by calixarenes, the complexation of simple molecular cations, i.e. $\mathrm{H}_{3} \mathrm{O}^{+}$and $\mathrm{NH}_{4}^{+}$, which are similar in size to $\mathrm{K}^{+}$and $\mathrm{Rb}^{+}$, has been rarely explored. Křiž et $a l^{22-24}$ studied the binding of oxonium ion with calix[4]arene esters, ketones and tetraacids by means of ${ }^{1} \mathrm{H}$ and ${ }^{13} \mathrm{C}$ NMR spectroscopy in acetonitrile and nitrobenzene, as well as by quantum chemical DFT in vacuo calculations. The experimentally obtained results indicated that complexation occurred through hydrogen bonding between the cation and both ether and carbonyl oxygen atoms of the ligand. In all cases $\mathrm{H}_{3} \mathrm{O}^{+}$ion was

\footnotetext{
$\dagger$ This article belongs to the Special Issue devoted to the $85^{\text {th }}$ anniversary of Croatica Chemica Acta.

* Author to whom correspondence should be addressed. (E-mail: vtomisic@chem.pmf.hr)
} 
more extensively hydrogen bonded with ether than with carbonyl oxygen atoms. The mentioned authors established that the $p$-tert-butylcalix[4]arene tetraacetic acid exhibited moderate affinity towards the oxonium ion in nitrobenzene $(\lg K=2.1){ }^{22}$ On the other hand, the stability constant of the complex of $\mathrm{H}_{3} \mathrm{O}^{+}$cation with $p$ tert-butylcalix[4]arene tetraacetate in acetonitrile was estimated to be much higher. ${ }^{23}$ The DFT in vacuo calculations were in accord with the experimental results. In the energetically most favourable complexes the hydrogen bonding of the cation with the phenoxyl oxygen atoms was preferred. Similarly, Dybal et al. ${ }^{25}$ examined the binding of $\mathrm{H}_{3} \mathrm{O}^{+}$ion by the p-tert-butyltetrathiacalix[4]arene tetraacetate. They established relatively high affinity of this receptor for the oxonium cation $(\lg K=5.1)$ in nitrobenzene. The results of DFT calculations were analogous to those obtained by Křiž et al. ${ }^{22-24}$ The binding of oxonium ion with a cali[4]arene secondary-amide derivative, namely $p$-tert-butylcalix[4]arene tetrakis( $N, N$-dimethylacetamide), was investigated by Makrlík et al. ${ }^{26}$ The stability of the complex formed in nitrobenzene was found to be quite high $(\lg K=10.9)$. The computational DFT based investigations revealed a preference of $\mathrm{H}_{3} \mathrm{O}^{+}$for the hydrogen bonding with amide carbonyl with respect to the ether oxygen atoms.

The complexation of $\mathrm{NH}_{4}^{+}$by calixarene derivatives functionalized at the lower rim was far less frequently explored. Makrilík et $a l^{27}$ investigated the binding of this cation with $p$-tert-butyltetrathiacalix[4]arene tetraacetate in nitrobenzene. The affinity of this macrocycle towards ammonium cation was found to be somewhat lower $\left(\lg K=4.3\right.$ ) than that for $\mathrm{H}_{3} \mathrm{O}^{+}$(Ref. 25), indicating the preference of the receptor for the smaller ion.

In the present work we have studied the complexation of $\mathrm{NH}_{4}^{+}$and $\mathrm{H}_{3} \mathrm{O}^{+}$by two calix[4] arene amino acid derivatives $\mathbf{1}$ and $\mathbf{2}$ (Figure 1) in acetonitrile (MeCN) and methanol $(\mathrm{MeOH})$. The main goal of the investigations was the quantitative description of the thermody-

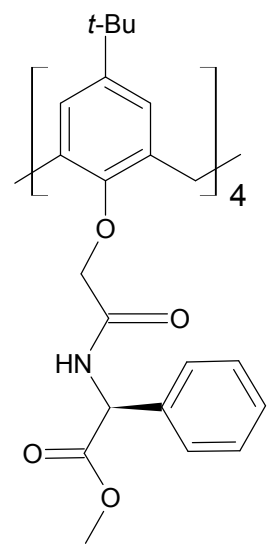

1

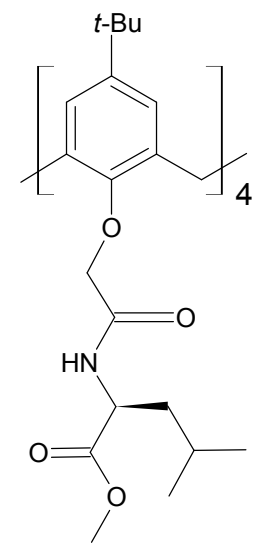

2
Figure 1. Structures of compounds 1 and 2. namics of complexation reactions. To shed more light on the possible structures of the ligands and their complexes in MeCN, classical molecular dynamics (MD) simulations were performed as well. The conjoined experimental and computational approach has provided a deeper insight into the factors governing the binding of ammonium and oxonium cations by the examined calixarene derivatives. The influences of the cation solvation, its size and the hydrogen bonding with the ligands on the reactions studied were particularly addressed.

\section{EXPERIMENTAL}

\section{Materials}

Compounds $\mathbf{1}$ and $\mathbf{2}$ were prepared according to the procedures described elsewhere. ${ }^{19}$ The binding of $\mathrm{H}_{3} \mathrm{O}^{+}$ and $\mathrm{NH}_{4}{ }^{+}$in acetonitrile (Merck, Uvasol) was studied by the addition of $\mathrm{HClO}_{4}$ (Merck, $70 \%$ suprapur) or $\mathrm{NH}_{4} \mathrm{ClO}_{4}$ (Sigma-Aldrich, $99.8 \%$ ) to the solutions of hosts. The same procedure was applied in the case of methanol (Merck, Uvasol) as a solvent. The solvents were used without further purification. The stock solutions of perchloric acid were prepared from the concentrated aqueous $\mathrm{HClO}_{4}$ solution and were diluted with acetonitrile or methanol to appropriate concentrations. A small amount of water $\left(\varphi\left(\mathrm{H}_{2} \mathrm{O}\right)=5 \%\right)$ was added to acetonitrile in order to ensure the presence of $\mathrm{H}_{3} \mathrm{O}^{+}$ species and to suppress the formation of acetamide (an intermediate in acetonitrile hydrolysis) in water free acidic medium. ${ }^{28}$ The solutions of the ligands were also prepared using acetonitrile with the same content of water. It should be noted that we have spectrophotometrically and potentiometrically observed that a process involving hydrogen ions took place in the freshly prepared $\mathrm{HClO}_{4}$ solutions which equilibrated after approximately 48 hours. For that reason, the solutions were prepared at least $48 \mathrm{~h}$ prior to use, and than standardized potentiometrically with aqueous solution of tris(hydroxymethyl)aminomethane (Aldrich, $99.9 \%$, ultrapure grade).

\section{Spectrophotometry}

UV titrations were performed at $(25.0 \pm 0.1){ }^{\circ} \mathrm{C}$ by means of a Varian Cary 5 double-beam spectrophotometer equipped with a thermostatting device. The spectral changes of 1 and 2 solutions $\left(V_{0}=2.2 \mathrm{~cm}^{3}\right.$, $c_{0}=1 \times 10^{-4}$ to $2 \times 10^{-4} \mathrm{~mol} \mathrm{dm}^{-3}$ ) were recorded upon stepwise addition of $\mathrm{HClO}_{4}\left(c=5 \times 10^{-3} \mathrm{~mol} \mathrm{dm}^{-3}\right)$ or $\mathrm{NH}_{4} \mathrm{ClO}_{4}\left(c=2.5 \times 10^{-2} \mathrm{~mol} \mathrm{dm}{ }^{-3}\right.$ or $\left.4 \times 10^{-2} \mathrm{~mol} \mathrm{dm}^{-3}\right)$ solution directly into the measuring quartz cell (Hellma, Suprasil QX, $l=1 \mathrm{~cm}$ ). Absorbances were sampled at $1 \mathrm{~nm}$ intervals, with an integration time of $0.2 \mathrm{~s}$. All measurements were done in triplicate. The obtained spectrophotometric data were processed using HYPERQUAD $^{29}$ and ORIGINPRO 7.5 programs. 


\section{Calorimetry}

Microcalorimetric measurements were performed by an isothermal titration calorimeter Microcal VP-ITC at $25.0{ }^{\circ} \mathrm{C}$. In the calorimetric titrations, the enthalpy changes obtained upon stepwise, automatic addition of $\mathrm{NH}_{4} \mathrm{ClO}_{4}\left(c=4 \times 10^{-2} \mathrm{~mol} \mathrm{dm}{ }^{-3}\right)$ or $\mathrm{HClO}_{4}\left(c=7 \times 10^{-3}\right.$ mol dm$\left.{ }^{-3}\right)$ to solutions of 1 and $2\left(c=2 \times 10^{-4} \mathrm{~mol} \mathrm{dm}^{-3}\right.$ to $7 \times 10^{-4} \mathrm{~mol} \mathrm{dm}^{-3}$ ) were recorded. Blank experiments were performed in order to eliminate the enthalpy changes corresponding to titrans dilution in pure solvent. The dependence of successive enthalpy change on the titrans volume was processed by non-linear leastsquare fitting procedure using ORIGINPRO 7.0 program. Titrations for each cation/ligand system were repeated three or more times.

The reliability of calorimeter was checked by carrying out the complexation of barium(II) by 18-crown- 6 in aqueous medium at $25{ }^{\circ} \mathrm{C}$. The results obtained $(\lg K=$ $3.75, \Delta_{\mathrm{r}} H=-31.7 \mathrm{~kJ} \mathrm{~mol}^{-1}$ ) were in good agreement with the literature values $\left(\lg K=3.73, \Delta_{\mathrm{r}} H=-31.5 \mathrm{~kJ} \mathrm{~mol}^{-1}\right){ }^{30}$

\section{Molecular Dynamics Simulations}

The molecular dynamics simulations were carried out by means of a GROMACS ${ }^{31}$ package (version 4.5.3). Intramolecular and nonbonded intermolecular interactions in calixarene ligands and $\mathrm{NH}_{4}^{+}$cation were modelled by the OPLS-AA (Optimized Parameters for Liquid Simulations-All Atoms) force field. ${ }^{32}$ Partial charges assigned to ring carbons bound to $\mathrm{CH}_{2}$ groups that link the monomers were assumed to be zero as described in Ref. 33. The initial structures of the free ligands were those in which the calixarene basket had a conformation of a $C_{4}$ square cone. Bond stretching and angle bending parameters for $\mathrm{H}_{3} \mathrm{O}^{+}$ion were those of TIP3P water and partial charges of hydrogen and oxygen atoms were taken from Ref. 34. The initial structures of the calixarene complexes were made by placing a cation in the center of lower rim cavity between ether and carbonyl oxygen atoms. In the case of $\mathrm{H}_{3} \mathrm{O}^{+}$complexes two different initial structures were used, one with hydrogen atoms of hydronium cation facing the ligand ether oxygen atoms, the one with the opposite orientation. The $\mathrm{CL}^{+}$species $\left(\mathrm{C}^{+}\right.$denotes the molecular cation) were solvated in a cubical box (edge length $58.5 \AA$ ) of acetonitrile with 2750 molecules, and with periodic boundary conditions. Solute concentration in such a box was about $0.01 \mathrm{~mol} \mathrm{dm}^{-3}$. Solvent box was equilibrated prior to introducing the hosts and the corresponding cation complexes, with box density after equilibration being close to the experimental one within $5 \%$. During the simulations of the systems, $\mathrm{Cl}^{-}$ion was included to neutralize the box. The chloride counterion was held fixed at the box periphery whereas the complex was initially positioned at the box center. In all simulations an energy minimization procedure was performed followed by a molecular dynamics simulation in $N p T$ conditions for $50.5 \mathrm{~ns}$, where first 0.2 ns were not used in the data analysis. Whenever an association of calixarene complex with the chloride anion was observed, the corresponding data were discarded and more simulations were performed in order to bring the total simulation time to about $50 \mathrm{~ns}$. Therefore, due to the $\mathbf{1} \cdot \mathrm{MeCN} \cdot \mathrm{H}_{3} \mathrm{O}^{+}-\mathrm{Cl}^{-}$and $\mathbf{1} \cdot \mathrm{MeCN} \cdot \mathrm{NH}_{4}{ }^{+}-\mathrm{Cl}^{-}$associations two simulations for each complex were performed with their duration being $25 \mathrm{~ns}$. The Verlet algorithm ${ }^{35}$ with a time step of 1 fs was employed. Cutoff radius for nonbonded van der Waals and short-range Coulomb interactions was $16 \AA$. Long-range Coulomb interactions were treated by the Ewald method as implemented in the PME (Particle Mesh Ewald) procedure. ${ }^{36,37}$ Simulation temperature was kept at 298.15 with NooseHover $^{38,39}$ algorithm using a time constant of 1 ps. Pressure was kept at 1 bar by Martyna-Tuckerman-TobiasKlein ${ }^{40}$ algorithm and a time constant of 1 ps.

\section{RESULTS AND DISCUSSION}

Upon addition of $\mathrm{NH}_{4} \mathrm{ClO}_{4}$ or $\mathrm{HClO}_{4}$ into the acetonitrile solutions of $\mathbf{1}$ and $\mathbf{2}$ a hypochromic effect on the larger part of the UV spectra of the ligands was observed, accompanied by the occurrence of isosbestic point(s). As examples of the obtained spectrophotometric data, the results of titrations of 1 with $\mathrm{HClO}_{4}$ and 2 with $\mathrm{NH}_{4} \mathrm{ClO}_{4}$ are shown in Figures 2 and 3, respectively.

The stability constants of the ammonium complexes with the investigated calixarene derivatives, obtained by processing the collected titration data according to a simple 1:1 binding model, are listed in Table 1.

For the quantitative description of the complexation equilibria involving $\mathrm{H}_{3} \mathrm{O}^{+}$and the examined macrocycles, the presence of several species comprised of $\mathrm{H}^{+}$and various number $(n)$ of water molecules $(n=$ 1-4) in $\mathrm{HClO}_{4}(\mathrm{MeCN})$ with added water has to be taken into account. The values of the equilibrium constants for the formation of $\mathrm{H}\left(\mathrm{H}_{2} \mathrm{O}\right)_{n}{ }^{+}$cations were taken from the literature, ${ }^{28}$ and were used in the processing of the collected spectrophotometric data. The obtained values of the stability constants of $\mathrm{H}_{3} \mathrm{O}^{+}$complexes with the investigated ligands in acetonitrile are given in Table 1.

The addition of $\mathrm{HClO}_{4}$ or $\mathrm{NH}_{4} \mathrm{ClO}_{4}$ into the methanol solutions of the examined calixarene derivatives did not cause any significant changes in the corresponding UV spectra, indicating very weak or non-existent complexation in this solvent.

The complexation of $\mathrm{H}_{3} \mathrm{O}^{+}$and $\mathrm{NH}_{4}^{+}$by compounds $\mathbf{1}$ and $\mathbf{2}$ was also investigated by means of microcalorimetric titrations. Thermograms obtained by titrations of these macrocycles with $\mathrm{NH}_{4} \mathrm{ClO}_{4}$ in acetonitrile are shown in Figures $4 \mathrm{a}$ and $5 \mathrm{a}$. 

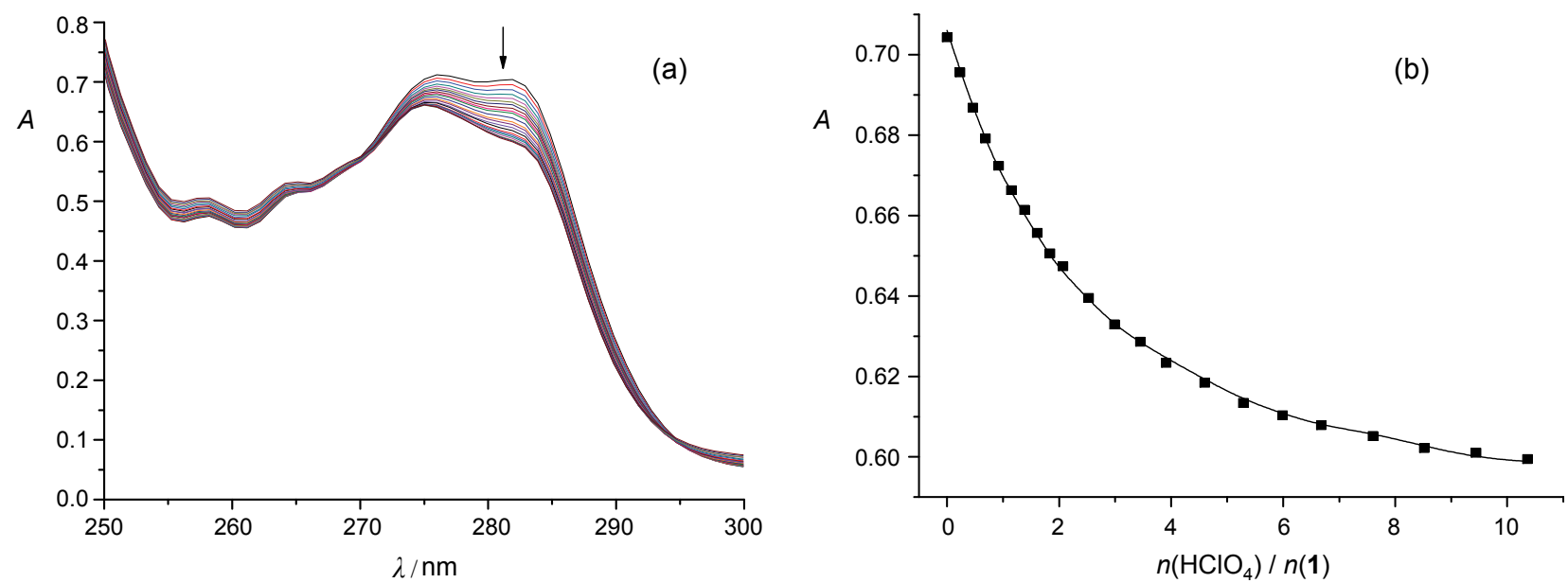

Figure 2. Spectrophotometric titration of $\mathbf{1}\left(c=2.0 \times 10^{-4} \mathrm{~mol} \mathrm{dm}{ }^{-3}, V_{0}=2.2 \mathrm{~mL}\right)$ with $\mathrm{HClO}_{4}\left(c=5.03 \times 10^{-3} \mathrm{~mol} \mathrm{dm}^{-3}\right)$ in acetonitrile. $l=1 \mathrm{~cm} ; \vartheta=(25.0 \pm 0.1){ }^{\circ} \mathrm{C}$. The spectra are corrected for dilution (a). Dependence of absorbance at $282 \mathrm{~nm}$ on $n\left(\mathrm{HClO}_{4}\right) / n(\mathbf{1})$ ratio, experimental (๘); calculated (一) (b).
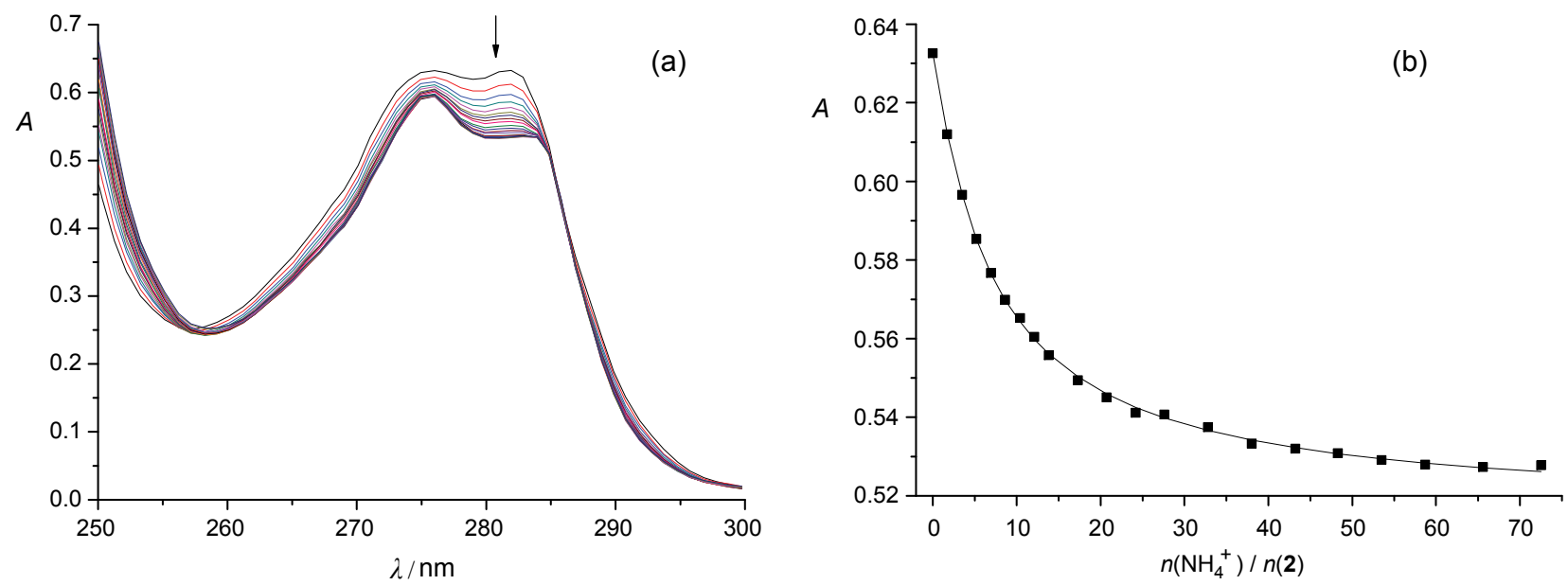

Figure 3. Spectrophotometric titration of $2\left(c=2.0 \times 10^{-4} \mathrm{~mol} \mathrm{dm}^{-3}, V_{0}=2.2 \mathrm{~mL}\right)$ with $\mathrm{NH}_{4} \mathrm{ClO}_{4}\left(c=4.0 \times 10^{-2} \mathrm{~mol} \mathrm{dm}^{-3}\right)$ in acetonitrile. $l=1 \mathrm{~cm} ; \vartheta=(25.0 \pm 0.1){ }^{\circ} \mathrm{C}$. The spectra are corrected for dilution (a). Dependence of absorbance at $282 \mathrm{~nm}$ on $n\left(\mathrm{NH}_{4} \mathrm{ClO}_{4}\right) / n(2)$ ratio, experimental (a); calculated (一) (b).

Table 1. Stability constants of the complexes of $\mathrm{NH}_{4}^{+}$and $\mathrm{H}_{3} \mathrm{O}^{+}$cations with $\mathbf{1}$ and $\mathbf{2}$ in acetonitrile at $25^{\circ} \mathrm{C}$.

\begin{tabular}{|c|c|c|c|}
\hline \multirow{3}{*}{ Ligand } & \multicolumn{3}{|c|}{$\lg K \pm \mathrm{SE}^{(\mathrm{a})}$} \\
\hline & \multicolumn{2}{|c|}{$\mathrm{NH}_{4}^{+}$} & $\mathrm{H}_{3} \mathrm{O}^{+}$ \\
\hline & spectrophotometry & microcalorimetry & spectrophotometry \\
\hline 1 & $2.64 \pm 0.07$ & $2.53 \pm 0.01$ & $4.82 \pm 0.05$ \\
\hline 2 & $2.95 \pm 0.01$ & $2.72 \pm 0.01$ & $4.93 \pm 0.06$ \\
\hline
\end{tabular}

(a) $\mathrm{SE}=$ standard error of the mean $(N=3-4)$

The stepwise addition of $\mathrm{NH}_{4} \mathrm{ClO}_{4}$ into solutions of $\mathbf{1}$ and $\mathbf{2}$ in acetonitrile resulted in exothermic enthalpy changes. The standard reaction enthalpies and the equilibrium constants (hence the standard reaction Gibbs energies) for the complexation of $\mathrm{NH}_{4}^{+}$with the examined calixarenes were determined by a leastsquares non-linear regression analysis of the calorimet- ric titration data (Figures $4 \mathrm{~b}$ and $5 \mathrm{~b}$ ). The standard reaction entropies were calculated by means of equations $\Delta_{\mathrm{r}} G^{\circ}=-R T \ln K$ and $\Delta_{\mathrm{r}} G^{\circ}=\Delta_{\mathrm{r}} H^{\circ}-T \Delta_{\mathrm{r}} S^{\circ}$. The obtained thermodynamic parameters are listed in Table 2.

Due to the fact that the reaction enthalpies for the formation of $\left[\mathrm{H}\left(\mathrm{H}_{2} \mathrm{O}\right)_{n}\right]^{+}(n=1-4)$ cations in acetonitrile were not available, the enthalpies of $\mathrm{H}_{3} \mathrm{O}^{+}$ 

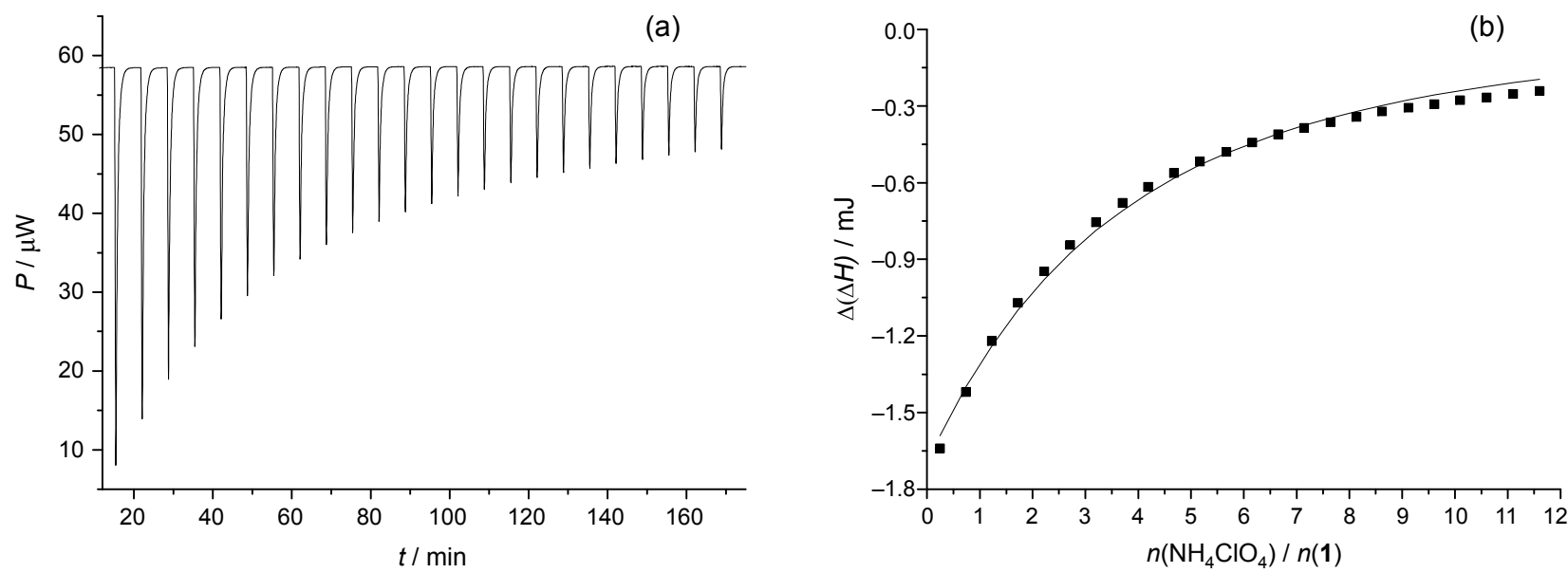

Figure 4. Microcalorimetric titration of $1\left(c=5 \times 10^{-4} \mathrm{~mol} \mathrm{dm}^{-3}, V=1.42 \mathrm{ml}\right)$ with $\mathrm{NH}_{4} \mathrm{ClO}_{4}\left(c=3.5 \times 10^{-2} \mathrm{~mol} \mathrm{dm}^{-3}\right)$ in acetonitrile at $25^{\circ} \mathrm{C}(\mathrm{a})$; Dependence of successive enthalpy change on $n\left(\mathrm{NH}_{4} \mathrm{ClO}_{4}\right) / n(\mathbf{1})$ ratio, experimental (- $)$; calculated (一) (b).
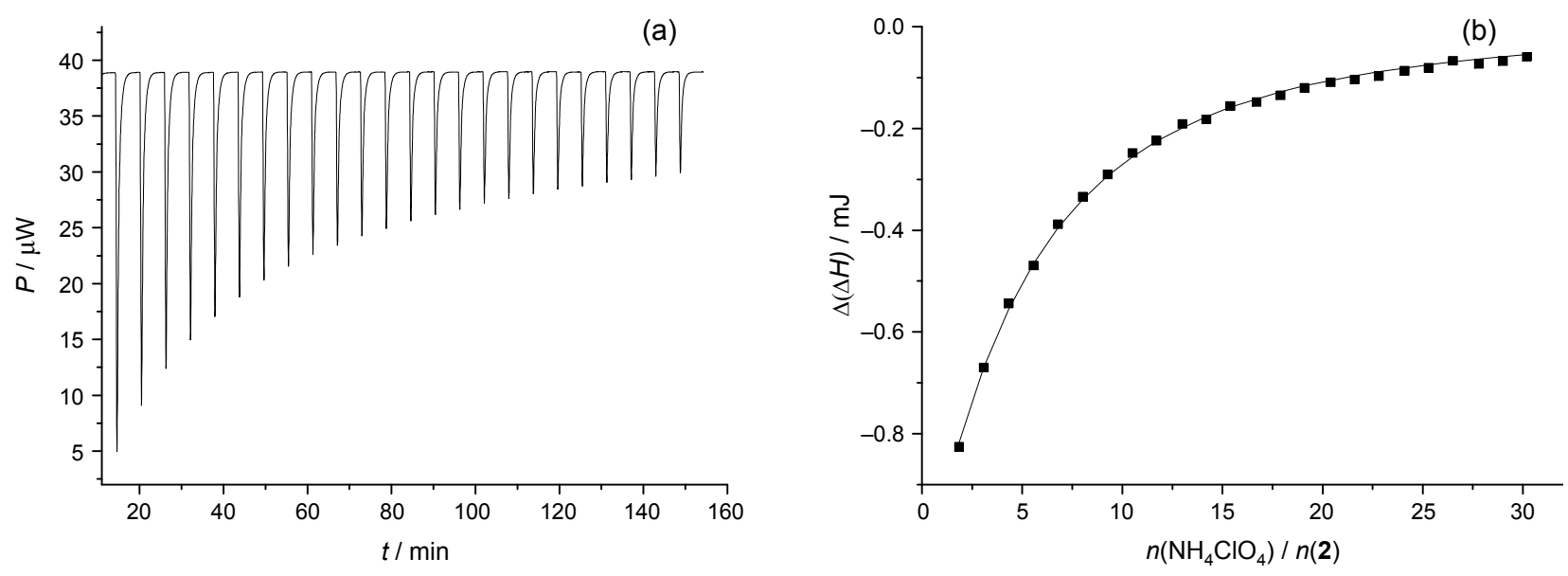

Figure 5. Microcalorimetric titration of $2\left(c=2 \times 10^{-4} \mathrm{~mol} \mathrm{dm}^{-3}, V=1.42 \mathrm{ml}\right)$ with $\mathrm{NH}_{4} \mathrm{ClO}_{4}\left(c=3.5 \times 10^{-2} \mathrm{~mol} \mathrm{dm}^{-3}\right)$ in acetonitrile at $25{ }^{\circ} \mathrm{C}\left(\right.$ a); Dependence of successive enthalpy change on $n\left(\mathrm{NH}_{4} \mathrm{ClO}_{4}\right) / n(2)$ ratio, experimental (匹); calculated (一) (b).

Table 2. Thermodynamic parameters for complexation of ammonium cation with calixarene derivatives $\mathbf{1}$ and $\mathbf{2}$ in acetonitrile at $25^{\circ} \mathrm{C}$.

\begin{tabular}{cccc}
\hline Ligand & $\left(\Delta_{\mathrm{r}} G^{\circ} \pm \mathrm{SE}\right)^{(\mathrm{a})} / \mathrm{kJ} \mathrm{mol}^{-1}$ & $\left(\Delta_{\mathrm{r}} H^{\circ} \pm \mathrm{SE}\right)^{(\mathrm{a})} / \mathrm{kJ} \mathrm{mol}^{-1}$ & $\left(\Delta_{\mathrm{r}} S^{\circ} \pm \mathrm{SE}\right)^{(\mathrm{a})} / \mathrm{J} \mathrm{K}^{-1} \mathrm{~mol}^{-1}$ \\
\hline $\mathbf{1}$ & $-14.31 \pm 0.01$ & $-36.26 \pm 0.06$ & $-73.2 \pm 0.2$ \\
$\mathbf{2}$ & $-15.53 \pm 0.07$ & $-30.4 \pm 0.6$ & $-50 \pm 2$ \\
\hline
\end{tabular}

(a) $\mathrm{SE}=$ standard error of the mean $(N=3)$

complexation with examined calixarenes could not be determined. The microcalorimetric titrations of both ligands with $\mathrm{HClO}_{4}\left(\mathrm{MeCN} / \mathrm{H}_{2} \mathrm{O}(\varphi=5 \%)\right)$ revealed that the binding of oxonium at specified solvent composition was accompanied by the positive enthalpy changes. However, it should be noted that even at such low content of water, the $\mathrm{H}^{+}$ion in solution is mostly present in the form of $\left[\mathrm{H}\left(\mathrm{H}_{2} \mathrm{O}\right)_{2}\right]^{+}$and $\left[\mathrm{H}\left(\mathrm{H}_{2} \mathrm{O}\right)_{3}\right]^{+}$cations. ${ }^{28}$ The formation of $\mathrm{H}_{3} \mathrm{O}^{+}$ion from these species is expected to be endothermic, which could in turn result in unfavourable enthalpy changes accompanying the complexation of oxonium ion under the conditions employed. However, one would reasonably anticipate the reactions of $\mathrm{H}_{3} \mathrm{O}^{+}$ cation with ligands $\mathbf{1}$ and $\mathbf{2}$ to be exothermic, as indicated by the results of MD simulations.

In order to obtain an insight into the structure of calixarene ligands $\mathbf{1}$ and $\mathbf{2}$ and their complexes with $\mathrm{H}_{3} \mathrm{O}^{+}$and $\mathrm{NH}_{4}^{+}$in solution, classical molecular dynamics simulations were performed. For both ligands, at the beginning of the simulation, the shape of the hydrophobic basket immediately changed from initial square cone ( $C_{4}$ symmetry) to a flattened cone $\left(C_{2}\right.$ symmetry). These 
(a)

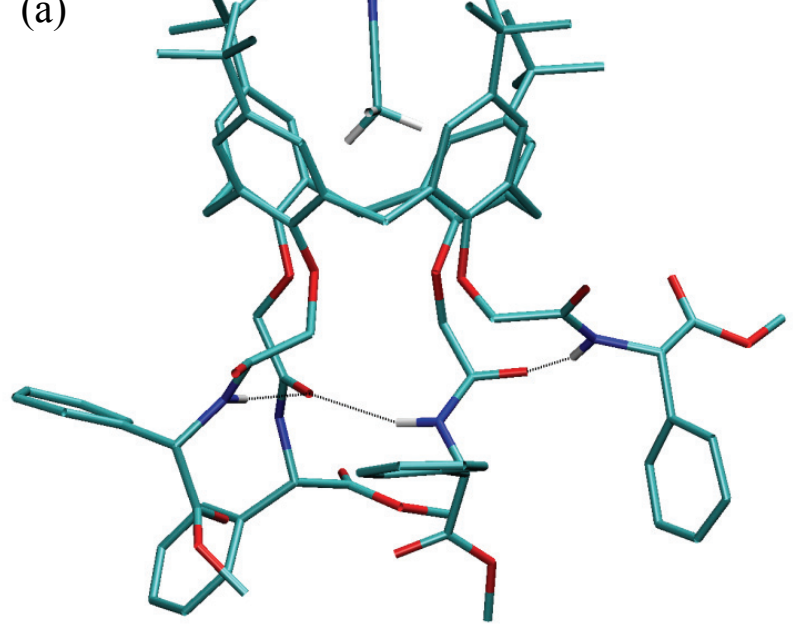

(b)

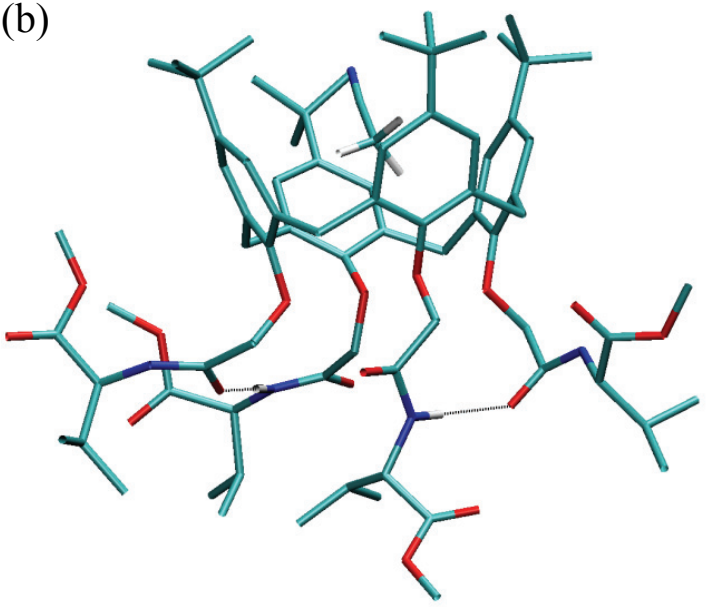

Figure 6. Structures of $\mathbf{1} \cdot \mathrm{MeCN}(\mathrm{a})$ and $\mathbf{2} \cdot \mathrm{MeCN}(\mathrm{b})$ adducts taken from a MD simulation snapshot. Hydrogen atoms that are not involved in hydrogen bonding are omitted for clarity.

conformational changes were reflected in the distances of the opposing aryl carbon atoms that are directly bound to tert-butyl groups (Figure S1). In the case of $C_{4}$ cone conformation these distances are the same, and in flattened cone they are different. After $1.66 \mathrm{~ns}$ for ligand $\mathbf{1}$ and 0.28 ns for ligand $\mathbf{2}$, an inclusion of acetonitrile molecule in the calixarene hydrophobic cone was observed (Figures S1 and S2). Unlike in the case of the calix[4]arene secondary-amide derivative which we studied earlier, ${ }^{11}$ after the inclusion of solvent molecule in 1 and 2 the shape of the cone remained somewhat flattened, although it resembled the regular square cone conformation. This deviation from $C_{4}$ symmetry is most likely due to the steric effects of the large substituents at the lower rim of the herein investigated ligands. In the MD simulations of the free ligand $\mathbf{1}$ the same solvent molecule that entered the basket remained in it until the end of simulation (50 ns). As for the ligand 2, four different acetonitrile molecules occupied the hydrophobic cavity during the simulation (Figure S2).

Both ligands are secondary-amide calixarene derivatives and have a possibility of forming intramolecular hydrogen bonds between the amide groups of the substituents. Indeed, the formation of two kinds of intramolecular $\mathrm{NH}^{\cdots} \mathrm{O}=\mathrm{C}$ hydrogen bonds was observed in the case of macrocycle $\mathbf{1}$, namely two-center and three-center ones. In the latter case, two hydrogen atoms were bound to one carbonyl oxygen. Criteria used for an interaction to be characterized as hydrogen bond were that the $\mathrm{N}-\mathrm{H}-\mathrm{O}$ angle was between $100^{\circ}$ and $180^{\circ}$, and that the distance between nitrogen and oxygen atoms was not larger than $3.5 \AA$. The number of intramolecular hydrogen bonds ranged from 0 to 3 , with an average for $\mathbf{1}$ being 1.43 , and for $\mathbf{1} \cdot \mathrm{MeCN} 2.33$. When two or more hydrogen bonds were formed, in $14 \%$ cases the three- center bond was found for $\mathbf{1}$, and $43 \%$ for $\mathbf{1} \cdot \mathrm{MeCN}$. The preference of free $\mathbf{1}$ to form mostly two-center hydrogen bonds can also be seen in the crystal structure of 1 where only these type of intra- and intermolecular H-bonds were observed. ${ }^{19}$ Concerning the ligand 2, on average 1.75 hydrogen bonds were formed during the simulation. No three-center bonds were observed. In $\mathbf{2} \cdot \mathrm{MeCN}$ adduct the average number of hydrogen bonds formed was 1.58 . When two or more hydrogen bonds were formed, in $11 \%$ cases three-center bond was found. Numbers of intramolecular hydrogen bonds are given in Table 3, whereas bond length and angle distributions of hydrogen bonds for both ligands and their acetonitrile adducts are presented in Figures $\mathrm{S} 3$ and $\mathrm{S} 4$.

The results of the MD simulations of $\mathrm{H}_{3} \mathrm{O}^{+}$complexes with the investigated ligands showed that the conformation of the calixarene basket in $\mathbf{L} \cdot \mathrm{H}_{3} \mathrm{O}^{+}$and $\mathbf{L} \cdot \mathrm{MeCN} \cdot \mathrm{H}_{3} \mathrm{O}^{+}$( $\mathbf{L}$ denotes $\mathbf{1}$ or $\mathbf{2}$ ) complexes was very close to the square cone (Figure S5). Immediately after the beginning of the simulations of $\mathbf{1} \cdot \mathrm{H}_{3} \mathrm{O}^{+}$and $\mathbf{2} \cdot \mathrm{H}_{3} \mathrm{O}^{+}$, an acetonitrile molecule entered the calixarene cone. During the simulations of both complexes, another two or three solvent molecules occupied the calixarene basket (Figure S6). A positive allosteric effect of cation binding on the inclusion of acetonitrile molecule was reflected in the time in which the cone was vacant which was reduced by more than an order of magnitude in the case of the $\mathbf{L} \cdot \mathrm{H}_{3} \mathrm{O}^{+}$species with respect to the free ligands.

Oxonium cation exhibited large orientational mobility in the calixarene cavity. Such mobility was also observed by Křiž et al. ${ }^{23,24}$ in the investigations of oxonium complexes with similar calixarene ligands. As a consequence of this mobility a diversity of structures, with respect to type and number of hydrogen bonds 
(a)

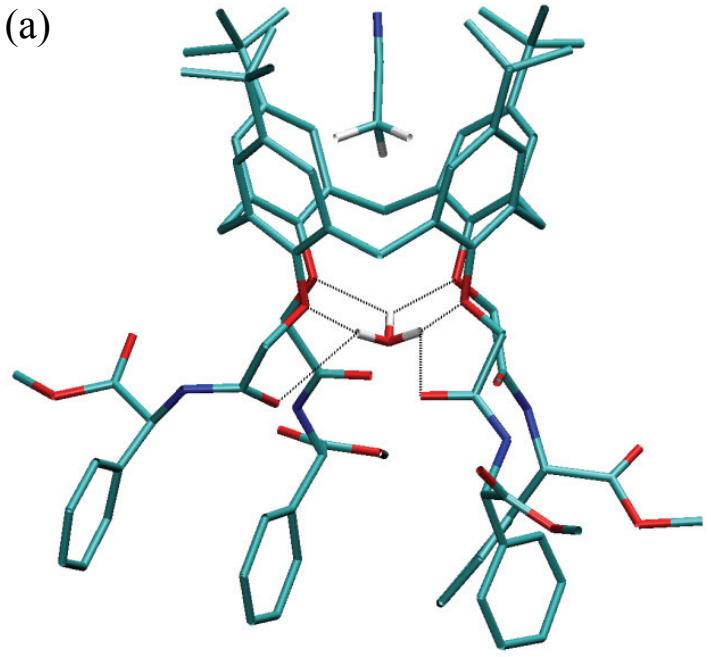

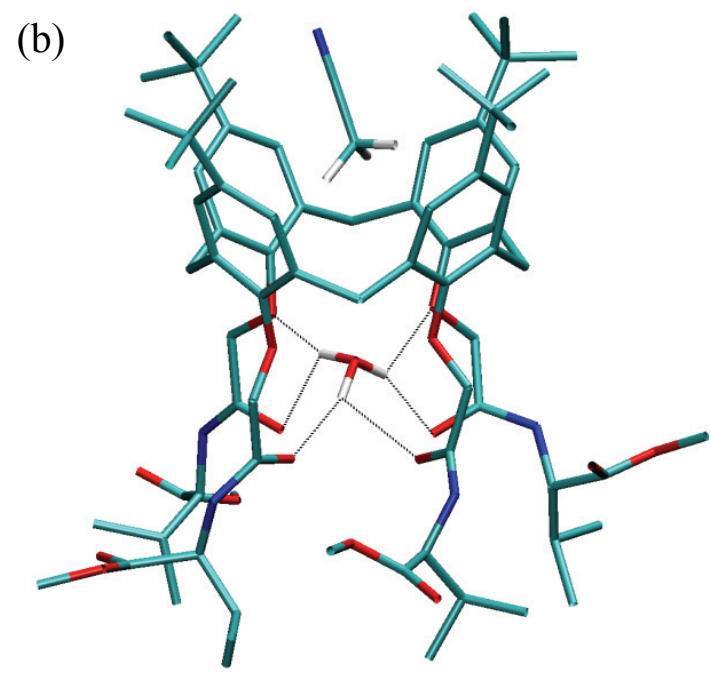

Figure 7. Structures of $\mathbf{1} \cdot \mathrm{MeCN} \cdot \mathrm{H}_{3} \mathrm{O}^{+},\{6,4,2,1,0,2,0,0\}$ (a), and $\mathbf{2} \cdot \mathrm{MeCN} \cdot \mathrm{H}_{3} \mathrm{O}^{+},\{6,2,4,0,1,2,0,0\}$ (b), complexes taken from a MD simulation snapshot. Hydrogen atoms of calixarene ligands are omitted for clarity.

between $\mathrm{H}_{3} \mathrm{O}^{+}$and calixarene ligand, were observed in the MD simulations. In order to classify these structures we have devised an indexing scheme based on the number and type of hydrogen bonds between $\mathrm{H}_{3} \mathrm{O}^{+}$and the ligand. The same scheme was also used for the complexes with $\mathrm{NH}_{4}^{+}$cation. To each structure of $\mathrm{CL}^{+}$complexes a following binding mode vector was assigned:

$$
\left\{N_{\text {tot }}, N_{\text {ether }}, N_{\text {carb }}, N_{3 c, \text { ether }}, N_{3 \mathrm{c}, \text { carb }}, N_{3 \mathrm{c}, \text { mixed }}, N_{4 \mathrm{c}, \text { ether }}, N_{4 \mathrm{c}, \text { carb }}\right\}
$$

where $N_{\text {tot }}$ denotes a total number of hydrogen bonds, $N_{\text {ether }}$ is a total number of H-bonds with ether oxygens, and $N_{\text {carb }}$ is a total number of H-bonds formed with amide carbonyl oxygens, $N_{3 c \text {,ether }}$ corresponds to a number of three-center H-bonds that involve two ether oxygens, $N_{3 c, \text { carb }}$ is an index of the three-center H-bonds with carbonyl oxygens, and $N_{3 c \text {,carb }}$ denotes a number of three-center hydrogen bonds with one ether and one carbonyl oxygen. $N_{4 \text { c,ether }}$ and $N_{4 \mathrm{c} \text {,carb }}$ correspond to the numbers of four-center hydrogen bonds with two ether and one carbonyl or two carbonyl and one ether oxygen atoms, respectively. Although the above scheme seems relatively complicated, it is a suitable way to categorize the variety of binding modes of $\mathrm{H}_{3} \mathrm{O}^{+}$and $\mathrm{NH}_{4}{ }^{+}$in $\mathrm{CL}^{+}$ complexes.

Criteria used for an interaction to be characterized as a hydrogen bond were that the donor-H-acceptor angle was between $100^{\circ}$ and $180^{\circ}$ and that the distance between hydrogen atom and acceptor oxygen atoms was not larger than $2.6 \AA$.

In the simulations of $1 \cdot \mathrm{H}_{3} \mathrm{O}^{+}$complex a number of 150 different structures were found, with ten most abundant structures making up $44 \%$ of total structure population. The most occurring structures for the studied calixarene complexes with oxonium cation are listed in Table S1. Two most abundant major classes were $\{6,4,2\}$ with $19 \%$ and $\{5,3,2\}$ with $17 \%$ occurrence ratio. Structure with the highest occurrence ratio of $6 \%$ was $\{6,4,2,1,0,2,0,0\}$ (Figure $7 \mathrm{a}$ ). In this rather symmetrical arrangement oxonium ion is bound to calixarene molecule with 6 hydrogen bonds, all of them being three-center ones (one is formed with two ether oxygen atoms and two of them are of mixed type, formed with one ether and one amide carbonyl oxygen atoms). During the simulation there were on average 5.65 hydrogen bonds formed between oxonium ion and the ligand 1, 3.34 of them being with ether oxygen and 2.31 with carbonyl oxygen atoms (Table 3 ). Hydrogen bonds with ether oxygen atoms were similar in average bond length and $\mathrm{O}-\mathrm{H}-\mathrm{O}$ angle to those formed with carbonyl oxygens, although their distributions are somewhat different (Figure S7).

Even though the oxonium ion binds to the proton acceptor atoms in the lower-rim hydrophilic cavity of the calixarene molecule, formation of intramolecular hydrogen bonds was observed in $\mathbf{1} \cdot \mathrm{MeCN} \cdot \mathrm{H}_{3} \mathrm{O}^{+}$complex (on average 0.47 bonds, Table 3 ).

Oxonium complex with ligand $\mathbf{2}$ was also studied by molecular dynamics simulations. Structure analysis resulted in 157 different structures. First 10 most occurring structures make $42 \%$ of total population. Major classes $\{6,4,2\}$ and $\{5,3,2\}$ were found to be dominating with occurrence ratio of $17 \%$ and $15 \%$, respectively, as was the case in the $\mathbf{1} \cdot \mathrm{MeCN} \cdot \mathrm{H}_{3} \mathrm{O}^{+}$complex. However, the structure that is most abundant, denoted as $\{6,2,4,0,1,2,0,0\}$, with occurrence ratio of $6 \%$, does not belong to these groups. In this structure one threecenter hydrogen bond with carbonyl oxygen atoms and two mixed three-center hydrogen bonds were present (Figure 7b). Second most abundant structure of 
Table 3. Average number of hydrogen bonds in ligands $\mathbf{1}$ and $\mathbf{2}$ and their complexes with $\mathrm{H}_{3} \mathrm{O}^{+}$and $\mathrm{NH}_{4}^{+}$obtained by MD simulations.

\begin{tabular}{|c|c|c|c|c|}
\hline Species & $N_{\text {intramol }}{ }^{(\text {a) }}$ & $N_{\text {cation }}{ }^{\text {(a) }}$ & $N_{\text {ether }}^{\text {(a) }}$ & $N_{\text {carbonyl }}^{\text {(a) }}$ \\
\hline 1 & 1.43 & - & - & - \\
\hline $\mathbf{1} \cdot \mathrm{MeCN}$ & 2.50 & - & - & - \\
\hline $\mathbf{1} \cdot \mathrm{H}_{3} \mathrm{O}^{+}$ & $-^{(\mathrm{b})}$ & $-^{(\mathrm{b})}$ & $-^{(\mathrm{b})}$ & $-^{(\mathrm{b})}$ \\
\hline $\mathbf{1} \cdot \mathrm{MeCN} \cdot \mathrm{H}_{3} \mathrm{O}^{+}$ & 0.47 & 5.65 & 3.34 & 2.31 \\
\hline $\mathbf{1} \cdot \mathrm{NH}_{4}^{+}$ & $-^{(\mathrm{b})}$ & $-^{(b)}$ & $-^{(b)}$ & $-^{(b)}$ \\
\hline $\mathbf{1} \cdot \mathrm{MeCN} \cdot \mathrm{NH}_{4}^{+}$ & 0.015 & 6.54 & 3.36 & 3.18 \\
\hline 2 & 1.75 & - & - & - \\
\hline 2. $\mathrm{MeCN}$ & 1.58 & - & - & - \\
\hline $2 \cdot \mathrm{H}_{3} \mathrm{O}^{+}$ & $-($b) & $-($b) & $-^{(\mathrm{b})}$ & $-{ }^{(b)}$ \\
\hline $\mathbf{2} \cdot \mathrm{MeCN} \cdot \mathrm{H}_{3} \mathrm{O}^{+}$ & 0.33 & 5.75 & 3.14 & 2.61 \\
\hline $\mathbf{2} \cdot \mathrm{NH}_{4}^{+}$ & $-($b) & $-^{(b)}$ & $-($ b) & $-($ b) \\
\hline $\mathbf{2} \cdot \mathrm{MeCN} \cdot \mathrm{NH}_{4}^{+}$ & 0.12 & 6.70 & 3.49 & 3.21 \\
\hline
\end{tabular}

${ }^{\text {(a) }} N_{\text {intramol }}$ - number of intramolecular hydrogen bonds, $N_{\text {cation }}$ - total number of hydrogen bonds formed between molecular cation and calixarene ligand, $N_{\text {ether }}$ - number of hydrogen bonds formed between molecular cation and ether oxygen atoms of calixarene ligand, $N_{\text {carbonyl }}$ - number of hydrogen bonds formed between molecular cation and carbonyl oxygen atoms of calixarene ligand.

(b) There was not enough data to make an analysis due to the short simulation time in which the species was observed.

$2 \cdot \mathrm{MeCN} \cdot \mathrm{H}_{3} \mathrm{O}^{+}$complex has the same binding mode vector values as the most occurring structure of $\mathbf{1} \cdot \mathrm{MeCN} \cdot \mathrm{H}_{3} \mathrm{O}^{+}$species.

The total number of hydrogen bonds between oxonium ion and ligand 2 was found to be on average 5.75 (3.14 with ether oxygen and 2.61 with carbonyl oxygen atoms, Table 3). The average values of hydrogen bond length and angle with ether oxygens were close to those corresponding to the bonds formed with carbonyl oxygens, but the distributions of these quantities were slightly different (Figure S8). Intramolecular hydrogen bonds were also present in $\mathbf{2} \cdot \mathrm{MeCN} \cdot \mathrm{H}_{3} \mathrm{O}^{+}$complex with the average of 0.33 bonds being formed throughout the simulation (Table 3).

Interaction energies between calixarene ligands and oxonium cation were also computed. The average value of the energy of $\mathbf{L}-\mathrm{H}_{3} \mathrm{O}^{+}$interaction was found to be $-400 \mathrm{~kJ} \mathrm{~mol}^{-1}$ for $1-\mathrm{H}_{3} \mathrm{O}^{+}$and $-416 \mathrm{~kJ} \mathrm{~mol}^{-1}$ for $2-\mathrm{H}_{3} \mathrm{O}^{+}$. These values are in rather good agreement with the interaction energy of oxonium ion with a similar ligand $\left(-407 \mathrm{~kJ} \mathrm{~mol}^{-1}\right)$ obtained by DFT calculations, ${ }^{24}$ which supports our choice of force field parameters for $\mathrm{H}_{3} \mathrm{O}^{+}$cation used in molecular dynamics simulations.

MD investigations of the complexes of $\mathrm{NH}_{4}^{+}$with $\mathbf{1}$ and $\mathbf{2}$ were also conducted. In both $\mathbf{1} \cdot \mathrm{NH}_{4}{ }^{+}$and $\mathbf{2} \cdot \mathrm{NH}_{4}{ }^{+}$at the beginning of the simulation an acetonitrile molecule entered the calixarene cone and remained there until the end of simulation (Figures S9 and S10). This indicated a strong positive allosteric effect of $\mathrm{NH}_{4}{ }^{+}$ complexation on the inclusion of $\mathrm{MeCN}$ molecule in the hydrophobic cavities of the ligands studied.
A larger number of binding modes was observed for $\mathbf{L} \cdot \mathrm{MeCN} \cdot \mathrm{NH}_{4}{ }^{+}$complexes compared to $\mathbf{L} \cdot \mathrm{MeCN} \cdot$ $\mathrm{H}_{3} \mathrm{O}^{+} ; 177$ for $\mathbf{1} \cdot \mathrm{MeCN} \cdot \mathrm{NH}_{4}{ }^{+}$and 224 for $\mathbf{2} \cdot \mathrm{MeCN} \cdot-$ $\mathrm{NH}_{4}^{+}$. The most occurring structures for the studied calixarene complexes with ammonium cation are listed in Table S1. Ten most abundant binding modes between ammonium cation and ligand $\mathbf{1}$ make $51.8 \%$ of structure population. The most dominating major classes of $\mathbf{1} \cdot \mathrm{MeCN} \cdot \mathrm{NH}_{4}{ }^{+}$complex were found to be $\{6,3,3\},\{7,4,3\}$ and $\{8,4,4\}$ with the occurrence ratios of $17.5 \%, 16.7 \%$ and $16.3 \%$, respectively. The most abundant structure from $\{6,3,3\}$ class was $\{6,3,3,0,1,1,0,0\}$ (Figure 8a) with $6.8 \%$ occurrence ratio. In this structure ammonium cation is bound to ligand 1 by two hydrogen bonds with ether oxygen atoms, one carbonyl oxygen three-center hydrogen bond, and one mixed three-center hydrogen bond.

As for the ligand 2, ten most abundant structures made $44.3 \%$ of total structure population. The most dominant major classes were $\{7,4,3\}$ with $19.7 \%$, $\{8,4,4\}$ with $16.5 \%$ and $\{6,3,3\}$ with $15.7 \%$ of structure population. The structure with the highest occurrence ratio of $5.2 \%$ was the one with the values of binding mode vector being $\{7,4,3,1,0,2,0,0\}$ (Figure 8b). In this structure one hydrogen bond is formed with amide carbonyl oxygen atom, one three-center H-bond is formed with ether oxygen atoms, and there are also two three-center H-bonds of mixed type.

The average number of the hydrogen bonds between ammonium cation and calixarene ligands was larger than in the corresponding calixarene-oxonium 
(a)

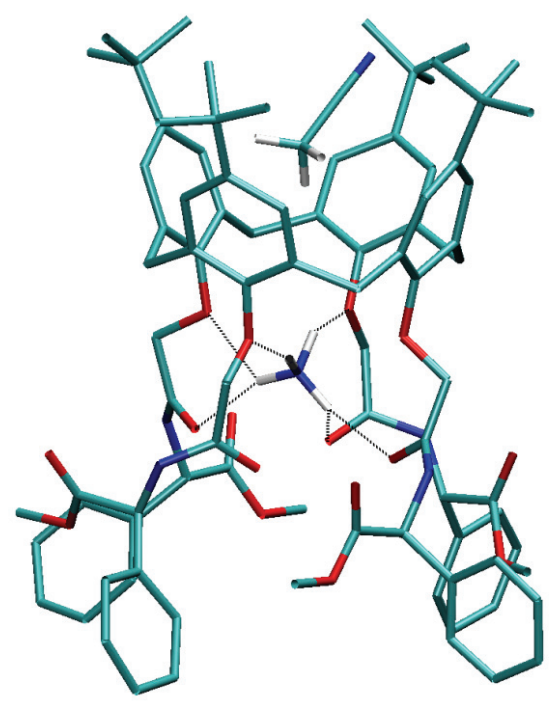

(b)

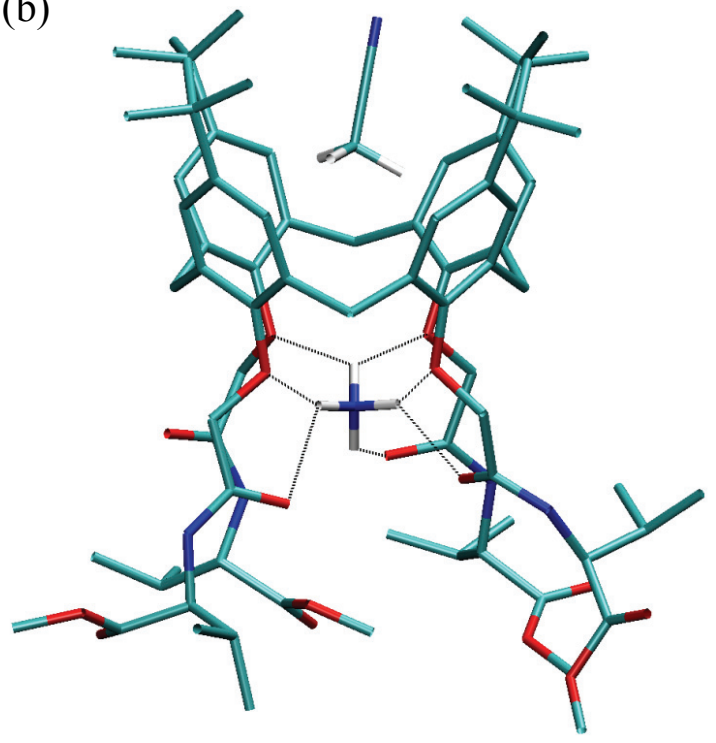

Figure 8. Structures of $\mathbf{1} \cdot \mathrm{MeCN} \cdot \mathrm{NH}_{4}{ }^{+},\{6,3,3,0,1,1,0,0\}$ (a), and $\mathbf{2} \cdot \mathrm{MeCN} \cdot \mathrm{NH}_{4}{ }^{+},\{7,4,3,1,0,2,0,0\}$ (b), complexes taken from a $\mathrm{MD}$ simulation snapshot. Hydrogen atoms of calixarene ligands are omitted for clarity.

complexes. During the simulation there were on average 6.54 hydrogen bonds formed in $\mathbf{1} \cdot \mathrm{MeCN} \cdot \mathrm{NH}_{4}^{+}$species, 3.36 with ether oxygen atoms and 3.18 with amide carbonyl oxygen atoms (Table 3 ). In $\mathbf{2} \cdot \mathrm{MeCN} \cdot \mathrm{NH}_{4}{ }^{+}$complex, ligand 2 formed on average 6.7 hydrogen bonds with ammonium cation, 3.49 of them being with ether oxygen atoms and 3.21 with carbonyl oxygen atoms (Table 3). Hydrogen bonds in $\mathbf{L} \cdot \mathrm{NH}_{4}{ }^{+}$complexes are of similar average lengths and angles with the distributions of these quantities for ether and carbonyl oxygen atoms being more alike than in the case of $\mathbf{L} \cdot \mathrm{MeCN} \cdot \mathrm{H}_{3} \mathrm{O}^{+}$ complexes (Figures S11 and S12). The number of intramolecular hydrogen bonds in $\mathbf{L} \cdot \mathrm{MeCN} \cdot \mathrm{NH}_{4}{ }^{+}$species was considerably lower than in the complexes of $\mathbf{L}$ with oxonium ion, or these bonds were non-existent (Table 3 ).

The absolute value of the average cation-ligand interaction energies for $\mathbf{L} \cdot \mathrm{MeCN} \cdot \mathrm{NH}_{4}^{+}$species are about $20 \mathrm{~kJ} \mathrm{~mol}^{-1}$ lower than those corresponding to $\mathbf{L} \cdot \mathrm{MeCN} \cdot \mathrm{H}_{3} \mathrm{O}^{+}$complexes.

The values of the stability constants presented in Table 1 reveal a considerable preference of the examined macrocycles towards oxonium with respect to ammonium cation. The well-known factor with a direct impact on the complex stability is the compatibility of the cation and calixarene hydrophilic cavity sizes. The oxonium cation $\left(r\left(\mathrm{H}_{3} \mathrm{O}^{+}\right)=1.30 \AA\right.$, coordination number $(\mathrm{CN})=6)^{41}$ similar in size to potassium $\left(r\left(\mathrm{~K}^{+}\right)=\right.$ $1.33 \AA, \mathrm{CN}=6),{ }^{41}$ fits well into the calix[4]arene ionbinding site, so its binding with the oxygen atoms of the ligand is expected to be quite favourable. On the other hand, the complexation of larger ammonium cation $\left(r\left(\mathrm{NH}_{4}{ }^{+}\right)=1.48 \AA, \mathrm{CN}=6\right)^{41}$ should be less advantageous. When comparing the stabilities of the herein reported complexes, apart from cation size, a hydrogen bonding of $\mathrm{H}_{3} \mathrm{O}^{+}$and $\mathrm{NH}_{4}{ }^{+}$with ether and amide carbonyl oxygen atoms of the ligands should also be taken into account. The structures of the complexes obtained by MD simulations suggest that the ammonium cation is more extensively hydrogen bonded than the oxonium one. As mentioned earlier, in the complexes $1 \cdot \mathrm{MeCN} \cdot$ $\mathrm{NH}_{4}{ }^{+}$and $2 \cdot \mathrm{MeCN} \cdot \mathrm{NH}_{4}{ }^{+}$, on average 6.54 and 6.70 hydrogen bonds were formed, respectively, whereas in the cases of $\mathbf{1} \cdot \mathrm{MeCN} \cdot \mathrm{H}_{3} \mathrm{O}^{+}$and $\mathbf{2} \cdot \mathrm{MeCN} \cdot \mathrm{H}_{3} \mathrm{O}^{+} 5.65$ and 5.75 such bonds were observed during the computational experiments. However, one should keep in mind that due to the difference in electronegativity of nitrogen and oxygen atoms $(\chi(\mathrm{O})=3.44 \mathrm{eV}, \chi(\mathrm{O})=3.04 \mathrm{eV}$ (Pauling) $)^{42}$ the oxonium cation should form stronger hydrogen bonds with host molecules. On the basis of the above considerations, one would expect interactions between oxonium ion and the investigated ligands to be more favourable than those corresponding to ammonium cation. The results of MD simulations support the above reasoning. Namely, the formation of the oxonium cation complexes with ligands $\mathbf{1}$ and $\mathbf{2}$ was found to be more energetically favourable than the formation of the corresponding complexes with the ammonium cation.

Prior to the inclusion into the hydrophilic ligand cavity, the cation must release directly and indirectly bound solvent molecules. Because of the mentioned differences in cation size and electronegativity of central atoms, $\mathrm{H}_{3} \mathrm{O}^{+}$should be more strongly solvated than $\mathrm{NH}_{4}{ }^{+}$. On the other hand, the number of hydrogen bonds that can be formed with acetonitrile molecules is larger in the case of ammonium cation, which could, in turn, result with more favourable solvation of this cation. 
Table 4. Thermodynamic parameters of monovalent cation complexation with phenylglycine calixarene derivative $\mathbf{1}$ and standard Gibbs enegies of cation solvation in $\mathrm{MeCN}$.

\begin{tabular}{ccccc}
\hline Cation & $\Delta_{\mathrm{r}} \mathrm{G}^{\circ} / \mathrm{kJ} \mathrm{mol}^{-1}$ & $\Delta_{\mathrm{r}} \mathrm{H}^{\circ} / \mathrm{kJ} \mathrm{mol}^{-1}$ & $\Delta_{\mathrm{r}} \mathrm{S}^{\circ} / \mathrm{J} \mathrm{K}^{-1} \mathrm{~mol}^{-1}$ & $\Delta_{\text {sol }} G^{\circ} / \mathrm{kJ} \mathrm{mol}^{-1}$ \\
\hline $\mathrm{H}_{3} \mathrm{O}^{+}$ & -27.4 & $-^{(\mathrm{a})}$ & $-{ }^{(\mathrm{a})}$ & - \\
$\mathrm{K}^{+}$ & $-24.6^{(\mathrm{b})}$ & $-40.3^{(\mathrm{b})}$ & $-50^{(\mathrm{b})}$ & $-296^{(\mathrm{c})}$ \\
$\mathrm{NH}_{4}^{+}$ & -14.31 & -36.26 & -73.2 & $-276^{(\mathrm{c})}$ \\
$\mathrm{Rb}^{+}$ & $-{ }^{(\mathrm{b}),(\mathrm{d})}$ & $-{ }^{(\mathrm{b}),(\mathrm{d})}$ & $-^{(\mathrm{b}),(\mathrm{d})}$ & $-275^{(\mathrm{c})}$ \\
\hline
\end{tabular}

(a) Could not be determined.

(b) Data from Ref. 10.

(c) Calculated from the Gibbs energy of cation hydration and the Gibbs energy of transfer from $\mathrm{H}_{2} \mathrm{O}$ to $\mathrm{MeCN}^{4}{ }^{41}$

${ }^{(d)}$ No complexation was observed.

Unfortunately, thermodynamic parameters for $\mathrm{H}_{3} \mathrm{O}^{+}$ solvation in acetonitrile, needed to take into account the differences in cation solvation from the thermodynamic point of view, could not be found in the literature. However, the relative contribution of ammonium and oxonium ion solvation to the observed difference in the affinities of ionophores $\mathbf{1}$ and $\mathbf{2}$ towards these cations in $\mathrm{MeCN}$ can be estimated on the basis of the corresponding standard hydration Gibbs energies $\left(\Delta_{\text {hyd }} G^{\circ}\right)$. Namely, the large difference in $\Delta_{\text {hyd }} G^{\circ}$ between $\mathrm{H}_{3} \mathrm{O}^{+}$and $\mathrm{NH}_{4}^{+}\left(\Delta_{\text {hyd }} G^{\circ}\left(\mathrm{H}_{3} \mathrm{O}^{+}\right)=-424 \mathrm{~kJ} \mathrm{~mol}^{-1}, \Delta_{\text {hyd }} G^{\circ}\left(\mathrm{NH}_{4}^{+}\right)=\right.$ $\left.-335 \mathrm{~kJ} \mathrm{~mol}^{-1}\right)^{43}$ indicates that the thermodynamically more favourable solvation of the oxonium ion in $\mathrm{MeCN}$ could be expected as well, since the standard Gibbs energies of transfer of cations from water to organic solvents $\left(\Delta_{\mathrm{tr}} G^{\circ}\right)$, by means of which solvation parameters in $\mathrm{MeCN}$ can be calculated, are typically much lower than $91 \mathrm{~kJ} \mathrm{~mol}^{-1}\left(\Delta_{\text {hyd }} G^{\circ}\left(\mathrm{NH}_{4}^{+}\right)-\Delta_{\text {hyd }} G^{\circ}\left(\mathrm{H}_{3} \mathrm{O}^{+}\right)\right)$. For instance, the standard Gibbs energy of transfer of ammonium cation from water to $\mathrm{MeCN}$, determined based on $\mathrm{Ph}_{4} \mathrm{AsPh}_{4} \mathrm{~B}$ convention, ${ }^{41}$ amounts to $16 \mathrm{~kJ}$ $\mathrm{mol}^{-1}$. The transfer of $\mathrm{H}_{3} \mathrm{O}^{+}$from water to acetonitrile would hence have to be quite endergonic (for more than $91 \mathrm{~kJ} \mathrm{~mol}^{-1}$ ) in order to result with less favourable solvation of oxonium with respect to ammonium ion in $\mathrm{MeCN}$. Consequently, from the point of view of cation solvation, the inclusion of ammonium ion is most likely favoured compared to $\mathrm{H}_{3} \mathrm{O}^{+}$. The experimentally observed higher affinity of $\mathbf{1}$ and $\mathbf{2}$ for $\mathrm{H}_{3} \mathrm{O}^{+}$ion can thus be explained by the more advantageous hydrogen bonding and stronger electrostatic interactions of oxonium cation with the calixarene binding sites.

It is interesting to compare the standard thermodynamic functions of $\mathrm{H}_{3} \mathrm{O}^{+}$and $\mathrm{NH}_{4}^{+}$complexation in acetonitrile with the corresponding values for the complexation of $\mathrm{K}^{+}$and $\mathrm{Rb}^{+}$, i.e. alkali-metal cations of comparable size. The direct comparison can only be made in the case of phenylglycine derivative whose affinity towards alkali metal cations was previously studied in detail. ${ }^{10}$ Nevertheless, due to the similar thermodynamic parameters for the complexation of $\mathrm{H}_{3} \mathrm{O}^{+}$and $\mathrm{NH}_{4}{ }^{+}$with both ligands, the conclusions made in the case of phenylglycine based receptor $\mathbf{1}$ should also hold for the leucine derivative 2 .

When the values of standard thermodynamic functions for the binding of different cations with the compound $\mathbf{1}$ are examined (Table 4), the appreciably lower affinity of the ligand for $\mathrm{NH}_{4}^{+}$with respect to $\mathrm{K}^{+}$becomes evident. From the point of view of cation solvation, the binding of ammonium is favoured over potassium cation, which can be seen from the fact that the standard Gibbs energy of potassium ion solvation in acetonitrile is $20 \mathrm{~kJ} \mathrm{~mol}^{-1}$ lower than that for ammonium one (Table 4). ${ }^{41}$ Likewise, the enthalpically beneficial formation of hydrogen bonds with host molecule should result in greater stability of $\mathbf{1} \cdot \mathrm{NH}_{4}^{+}$when compared to the corresponding potassium complex. The higher selectivity of phenylglycine calixarene derivative for $\mathrm{K}^{+}$could therefore be a consequence of the smaller radius of the alkali-metal cation $\left(r\left(\mathrm{~K}^{+}\right)=1.33 \AA\right.$; $\mathrm{CN}=$ 6, $\left.r\left(\mathrm{NH}_{4}^{+}\right)=1.48 \AA ; \mathrm{CN}=6\right){ }^{41}$

Interestingly, although the $\mathrm{Rb}^{+}$has quite similar radius to that of $\mathrm{NH}_{4}{ }^{+}\left(r\left(\mathrm{Rb}^{+}\right)=1.49 \AA ; \mathrm{CN}=6\right),{ }^{41}$ the complexation of this cation with ligand $\mathbf{1}$ in acetonitrile could not be observed. ${ }^{10}$ Since the solvation of rubidium cation in $\mathrm{MeCN}$ is, from the thermodynamical point of view, almost equal to that of ammonium cation (Table 4), the difference in the hosting ability of compound $\mathbf{1}$ for ammonium and rubidium ions clearly emphasizes the favourable influence of the hydrogen bonding with the molecular cation on the equilibrium of the complexation reaction.

Because of the lack of thermodynamic parameters for oxonium ion solvation in acetonitrile, a thermodynamic interpretation of the observed differences in the affinity of 1 for the alkali-metal cations compared to $\mathrm{H}_{3} \mathrm{O}^{+}$remains at somewhat speculative level. However, the large difference in standard hydration Gibbs energies between $\mathrm{H}_{3} \mathrm{O}^{+}$and $\mathrm{K}^{+}\left(\Delta_{\text {hyd }} G^{\circ}\left(\mathrm{H}_{3} \mathrm{O}^{+}\right)=-424 \mathrm{~kJ}\right.$ $\mathrm{mol}^{-1}$ (Ref. 43), $\Delta_{\text {hyd }} G^{\circ}\left(\mathrm{K}^{+}\right)=-345 \mathrm{~kJ} \mathrm{~mol}^{-1}$ (Ref. 41)) indicates that the solvation of oxonium ion in acetonitrile is expected to be more exergonic than the solvation of potassium cation. Consequently, due to the similar sizes of potassium and oxonium ions, and significantly 
more favourable hydration (and hence most likely solvation in $\mathrm{MeCN}$ ) of $\mathrm{H}_{3} \mathrm{O}^{+}$compared to $\mathrm{K}^{+}$, the phenylglycine based receptor should display higher affinity for $\mathrm{K}^{+}$than for $\mathrm{H}_{3} \mathrm{O}^{+}$. The observed preference of the ionophore 1 towards $\mathrm{H}_{3} \mathrm{O}^{+}$can, therefore, be explained by to the formation of hydrogen bonds between this cation and the pendant arms of the macrocycle.

The ability of calix[4] secondary-amide derivative 1 to host alkali-metal cations is largely reduced in methanol in comparison with acetonitrile. ${ }^{10,21}$ As solvations of this compound in $\mathrm{MeOH}$ and $\mathrm{MeCN}$ were found to be similar, ${ }^{10}$ the reason should lie in different solvations of the cation(s) and the complex(es) formed. Indeed, the solvation of the alkali-metal complexes with 1 was proven to play an important role in favouring the binding process in acetonitrile over methanol. That was attributed to the inclusion of $\mathrm{MeCN}$ molecule into the hydrophobic cavity of the complexed ligand. ${ }^{10}$ According to the results of MD simulations, the same reasoning can be applied in the case of the herein investigated complexation reactions.

The transfer of ammonium ion from methanol to acetonitrile is rather unfavourable $\left(\Delta_{\mathrm{tr}} G^{\circ}=10 \mathrm{~kJ} \mathrm{~mol}^{-1}\right)^{41}$. The stronger solvation of $\mathrm{NH}_{4}{ }^{+}$in $\mathrm{MeOH}$ hence opposes its binding with $\mathbf{1}$ and $\mathbf{2}$ in this solvent (which was not even observed), thereby favouring the complexation in $\mathrm{MeCN}$. Although the $\Delta_{\mathrm{tr}} G^{\circ}(\mathrm{MeOH} \rightarrow \mathrm{MeCN})$ value for $\mathrm{H}_{3} \mathrm{O}^{+}$is not available, the same conclusion can most likely be drawn in the case of complexation of this cation.

\section{CONCLUSION}

On the basis of the results of the MD simulations it could be concluded that free ligands $\mathbf{1}$ and $\mathbf{2}$ and their solvent adducts coexist in the acetonitrile solution. The existence of intramolecular hydrogen bonds between the amide groups of the substituents was observed for both 1 and 2, which most likely strongly affects the ionophoric properties of both ligands in acetonitrile..$^{10,21}$

The complexation of $\mathrm{NH}_{4}{ }^{+}$and $\mathrm{H}_{3} \mathrm{O}^{+}$results with substantial conformational changes of macrocycles $\mathbf{1}$ and 2, with the shape of basket resembling the $C_{4}$ square cone. Both cations exhibit relatively large mobility inside the binding sites of the calixarenes examined. On average, the number of hydrogen bonds with the substituents of the ligands is larger in the case of ammonium compared to oxonium cation. However, the complexes of $\mathbf{1}$ and $\mathbf{2}$ with the $\mathrm{H}_{3} \mathrm{O}^{+}$ion were found to be energetically more stable than the corresponding complexes with $\mathrm{NH}_{4}^{+}$cation. The preferable inclusion of $\mathrm{MeCN}$ molecule into the hydrophobic cavity of the complexes with respect to the free ligands was observed in all cases, which supports the hypothesis that the preorganisation of calixarene cavity is of great importance for the binding of the solvent molecule. ${ }^{16,44}$
The stability constants of the complexes were determined by means of spectrophotometric and microcalorimetric titrations. The values obtained by different methods are in satisfactory agreement. The results of calorimetric investigations indicate that complexation of $\mathrm{NH}_{4}{ }^{+}$ cation with $\mathbf{1}$ and $\mathbf{2}$ in acetonitrile is enthalpy driven.

The binding abilities of $\mathbf{1}$ and $\mathbf{2}$ for $\mathrm{H}_{3} \mathrm{O}^{+}$are much higher than those for $\mathrm{NH}_{4}^{+}$. The selectivity of the ligands towards oxonium with respect to ammonium cation in acetonitrile can be explained by taking into account the cation size and the more favourable hydrogen bonding of $\mathrm{H}_{3} \mathrm{O}^{+}$with the ether and amide carbonyl oxygen atoms of the examined ligands. The ammonium and oxonium complexes with ligand $\mathbf{1}$ are thermodynamically more stable than the corresponding complexes of alkali-metal ions of similar size, namely rubidium and potassium cations. The higher affinity for $\mathrm{NH}_{4}^{+}$ with respect to $\mathrm{Rb}^{+}$, and for $\mathrm{H}_{3} \mathrm{O}^{+}$with respect to $\mathrm{K}^{+}$, can be mostly attributed to the advantageous hydrogen bonding of molecular cations with the ion binding site of the compound $\mathbf{1}$.

The result of a remarkable influence of the solvent on the studied complexation equilibria was reflected in the fact that the complexation of the examined molecular cations by calix[4]arene derivatives $\mathbf{1}$ and $\mathbf{2}$ in methanol could not be observed at all.

Supplementary Materials. - Supporting informations to the paper are enclosed to the electronic version of the article. These data can be found on the website of Croatica Chemica Acta (http://public.carnet.hr/ccacaa).

Acknowledgements. This work was supported by the Ministry of Science, Education and Sports of the Republic of Croatia (projects 119-1191342-2960, 119-1191342-2961, and 098-09829042912). Computational resources were provided by the Croatian National Grid Infrastructure (www.cro-ngi.hr) at Zagreb University Computing Centre (Srce).

\section{REFERENCES}

1. C. D. Gutsche, Calixarenes: An Introduction, $2^{\text {nd }}$ ed., The Royal Society of Chemistry, Cambridge, 2008.

2. Z. Asfari, V. Böhmer, J. Harrowfield, and J. Vicens, (Eds.), Calixarenes 2001, Kluwer Academic Publishers, Dordrecht, 2001.

3. B. S. Craeven, D. F. Donlon, and J. Mcginley, Coord. Chem. Rev. 253 (2009) 893-962.

4. D. T.Schüle, J. A. Peters, and J. Schatz, Coord. Chem. Rev. 255 (2011) 2727-2745.

5. W. Abraham, J. Incl. Phenom. Macrocycl. Chem. 43 (2002) 159174.

6. W. Sliwa and T. Girek, J. Incl. Phenom. Macrocycl. Chem. 66 (2010) 15-41.

7. R. Ludwig and N. T. K. Dzung, Sensors 2 (2002) 397-416.

8. A. F. Danil de Namor, R. M. Cleverley, and M. L. ZapataOrmachea, Chem. Rev. 98 (1998) 2495-2525.

9. A. F. Danil de Namor, Thermodynamics of calixarene-ion interactions, in: Z. Asfari, V. Böhmer, J. Harrowfield, and J. Vicens, (Eds.), Calixarenes 2001, Kluwer Academic Publishers, Dor- 
drecht, 2001, pp. 346-364.

10. J. Požar, T. Preočanin, L. Frkanec, and V. Tomišić, J. Solution Chem. 39 (2010) 835-848.

11. G. Horvat, V. Stilinović, T. Hrenar, Branko Kaitner, L. Frkanec, and V. Tomišić, Inorg. Chem. 51 (2012) 6264-6278.

12. P. Cuř́nová, M. Pojarová, J. Budka, K. Lang, I Stibor, and P. Lhoták, Tetrahedron 66 (2010) 8047-8050.

13. G. Arena, A. Contino, E. Longo, G. Spoto, A. Arduini, A. Pochini, A. Secchi, C. Massera, and F. Ugozzolli, New J. Chem. 28 (2004) 56-61.

14. G. Arena, A. Continoa, A. Magrì, D. Sciottoa, A. Arduini, A. Pochini, and A. Secchi, Supramol. Chem. 13 (2001) 379-386.

15. A. Arduini, G. Giorgi, A. Pochini, A. Secchi, and F. Ugozzolli, Tetrahedron 57 (2001) 2411-2417.

16. S. Smirnov, V. Sidorov, V. Pinkhassik, J. Havlicek, and I. Stibor, Supramol. Chem. 8 (1997) 187-196.

17. A. F. Danil de Namor, N. Apaza de Sueros, M. A. McKervey, G. Barrett, F. Arnaud-Neu, and M. J. Schwing-Weill, J. Chem. Soc., Chem. Commun. 21 (1991) 1546-1548.

18. E. Nomura, M. Takagaki, C. Nakaoka, M. Uchida, and H. Taniguchi, J. Org. Chem. 64 (1999) 3151-3156.

19. L. Frkanec, A. Višnjevac, B. Kojić-Prodić, and M. Žinić, Chem. Eur. J. 6 (2000) 442-453.

20. N. Galić, N. Burić, R. Tomaš, L. Frkanec, and V. Tomišić, Supramol. Chem. 23 (2011) 389-397.

21. V. Tomišić, N. Galić, B. Bertoša, L. Frkanec,V. Simeon, and M. Žinić, J. Incl. Phenom. Macrocycl. Chem. 53 (2005) 263-268.

22. J. Kř́ž, J. Dybal, E. Makrlík, J. Budka, and P. Vaňura, Monatsh. Chem. 141 (2010) 19-22.

23. J. Kříž, J. Dybal, E. Makrlík, and P. Vaňura, Supramol. Chem. 20 (2008) 387-395.

24. J. Kříž, J. Dybal, E. Makrlík, J. Budka, and P. Vaňura, Monatsh Chem. 138 (2007) 735-740.

25. J. Dybal, E. Makrlík, J. Budka, P. Vaňura, and P. Selucký,
Monatsh. Chem. 138 (2007) 1239-1242.

26. E. Makrlík, J. Dybal, J. Budka, P. Vaňura, Monatsh. Chem. 140 (2009) 1155-1158.

27. E. Makrlík, P. Vaňura, J. Budka, and P. Selucký, Monatsh. Chem. 141 (2010) 31-33.

28. I. M. Kolthoff and M. K. Chantooni, Jr., J. Am. Chem. Soc. 90 (1968) 3320-3326.

29. P. Gans, A. Sabatini, and A. Vacca, Talanta 43 (1996) 1739-53.

30. J. Tellinghuisen, J. Phys. Chem. B 111 (2007) 11531-11537.

31. B. Hess, C. Kutzner, D. van der Spoel, and E. Lindahl, J. Chem. Theory Comput. 4 (2008) 435-447.

32. W. L. Jorgensen, D. S. Maxwell, and J. Tirado-Rives, J. Am. Chem. Soc. 118 (1996) 11225-11236.

33. A. S. de Araujo, O. E. Piro, E. E. Castellano, and A. F. Danil de Namor, J. Phys. Chem. A 112 (2008) 11885-11894.

34. S. L. Fornili, M. Migliore, and M. A. Palazzo, Chem. Phys. Lett. 125 (1986) 419-424.

35. W. C. Swope, H. C. Andersen, P. H. Berens, and K. R. Wilson, J. Chem. Phys. 76 (1982) 637-649.

36. T. Darden, D. York, and L. Pedersen, J. Chem. Phys. 98 (1993) 10089-10092.

37. U. Essmann, L. Perera, M. L. Berkowitz, T. Darden, H. Lee, and L. G. Pedersen, J. Chem. Phys. 103 (1995) 8577-8593.

38. S. Nosé, Mol. Phys. 52 (1984) 255-268.

39. W. Hoover, Phys. Rev. A 31 (1985) 1695-1697.

40. G. J. Martyna, M. E. Tuckerman, D. J. Tobias, and M. L. Klein, Mol. Phys. 87 (1996) 1117-1157

41. Y. Marcus, Ion Properties, M. Dekker, New York, 1997.

42. L. C. Allen, J. Am. Chem. Soc. 111 (1989) 9003-9014.

43. M. Meot-Ner (Mautner) and L. W. Sieck, J. Phys. Chem. B 100 (1996) 6445-6450.

44. A. F. Danil de Namor, M. L. Zapata-Ormachea, and R. G. Hutcherson, J. Phys. Chem. B 103 (1999) 366-371. 


\section{Complexation of oxonium and ammonium ions by lower-rim calix[4]arene amino acid derivatives}

\section{SUPPORTING INFORMATION}

Josip Požar, ${ }^{\mathrm{a}}$ Gordan Horvat, ${ }^{\mathrm{a}}$, Marina Čalogovića ${ }^{\mathrm{a}}$, Nives Galića ${ }^{\mathrm{a}}$ Leo Frkanec ${ }^{\mathrm{b}}$, Vladislav Tomišićc $\mathrm{a}^{*}$

${ }^{a}$ Department of Chemistry, Faculty of Science, University of Zagreb, Horvatovac 102a, 10000 Zagreb, Croatia

${ }^{\mathrm{b}}$ Department of Organic Chemistry and Biochemistry, Rudjer Bošković Institute, Bijenička 54, 10000 Zagreb, Croatia 

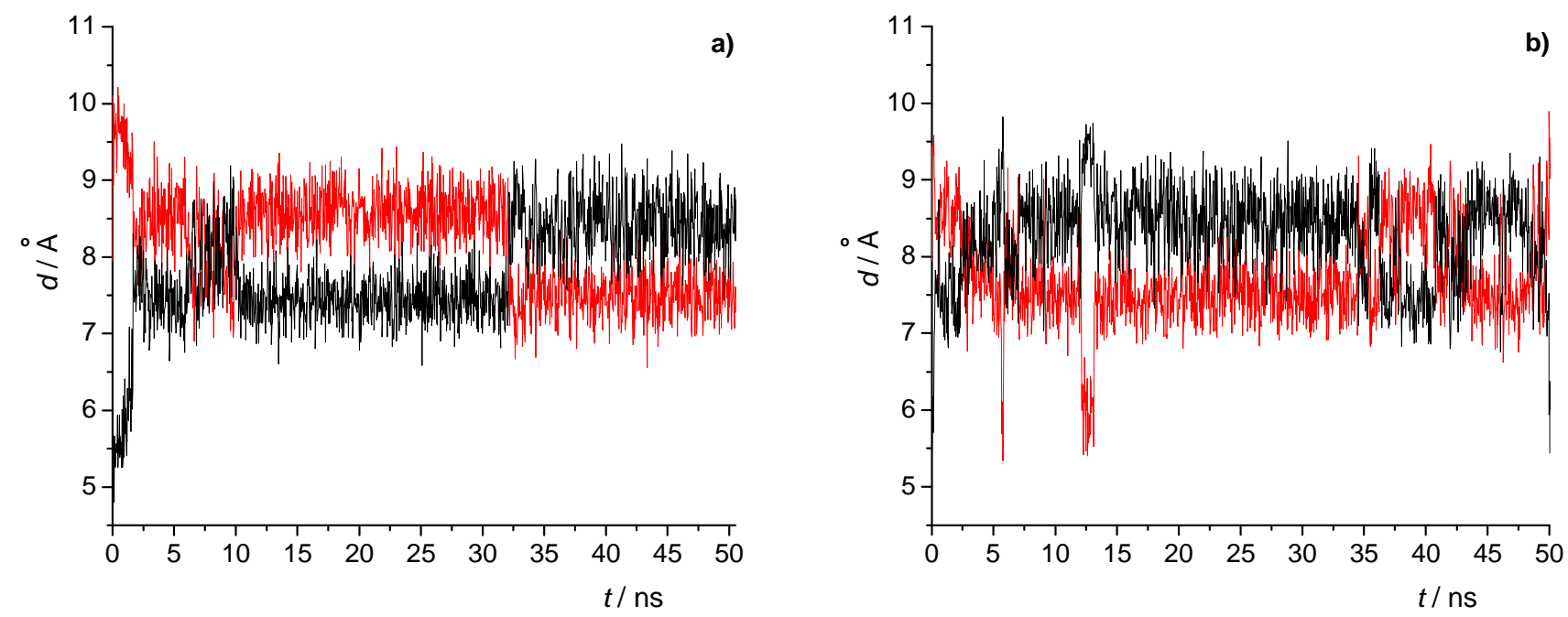

Figure S1. Distances between the opposing phenyl carbon atoms that are directly connected to the tertbutyl group during the MD simulations of a) ligand $\mathbf{1}$ and b) ligand $\mathbf{2}$ in acetonitrile at $25^{\circ} \mathrm{C}$.
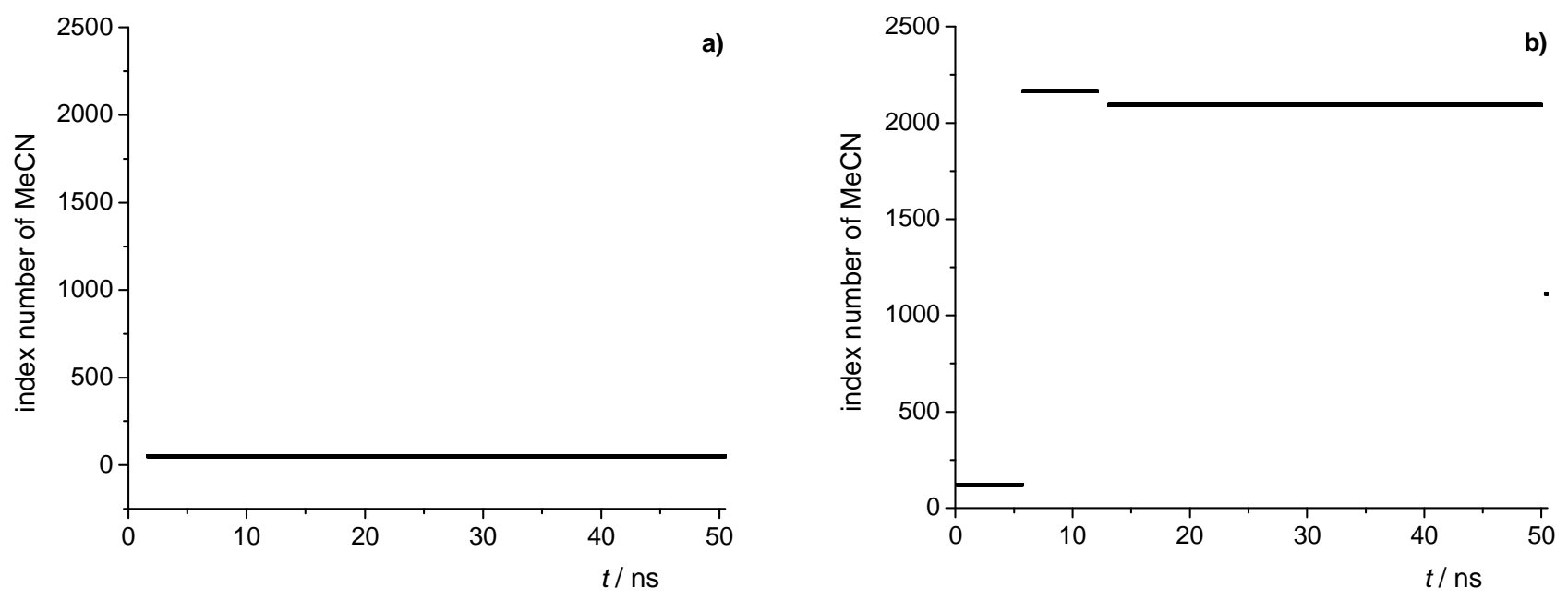

Figure S2. Index numbers of acetonitrile molecules that occupy hydrophobic cavity in a) ligand $\mathbf{1}$ and b) ligand 2 during MD simulations in acetonitrile at $25^{\circ} \mathrm{C}$. 

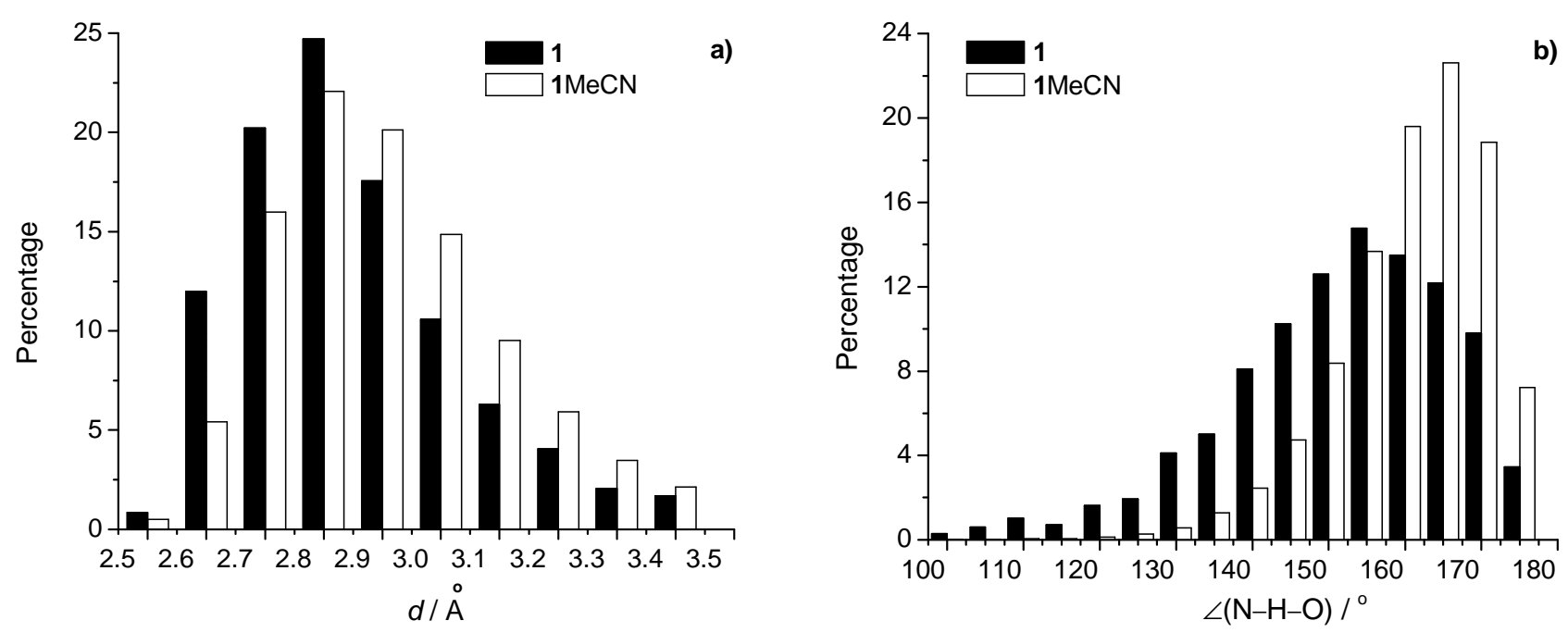

Figure S3. Hydrogen bond a) length and b) angle distributions for free $\mathbf{1}$ and $\mathbf{1} \cdot \mathrm{MeCN}$ obtained by MD simulations at $25{ }^{\circ} \mathrm{C}$.
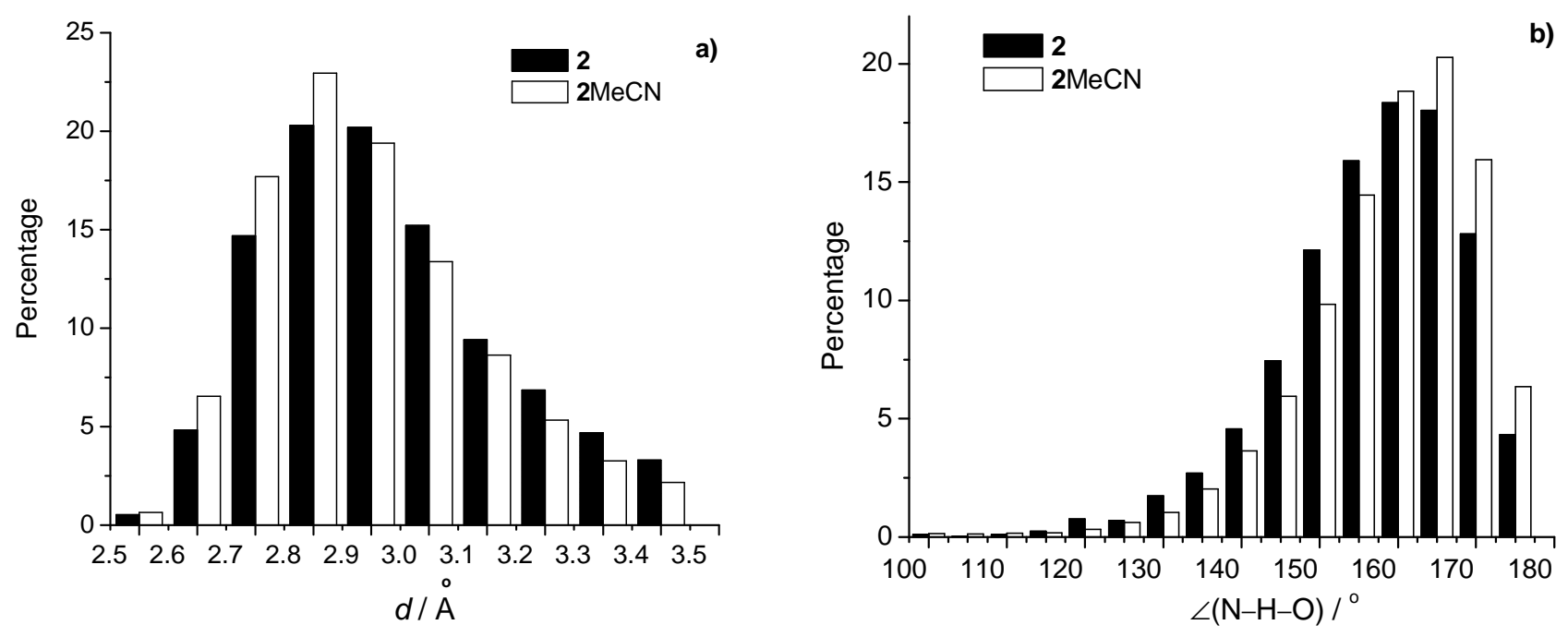

Figure S4. Hydrogen bond a) length and b) angle distributions for free $\mathbf{2}$ and $\mathbf{2} \cdot \mathrm{MeCN}$ obtained by MD simulations at $25{ }^{\circ} \mathrm{C}$. 

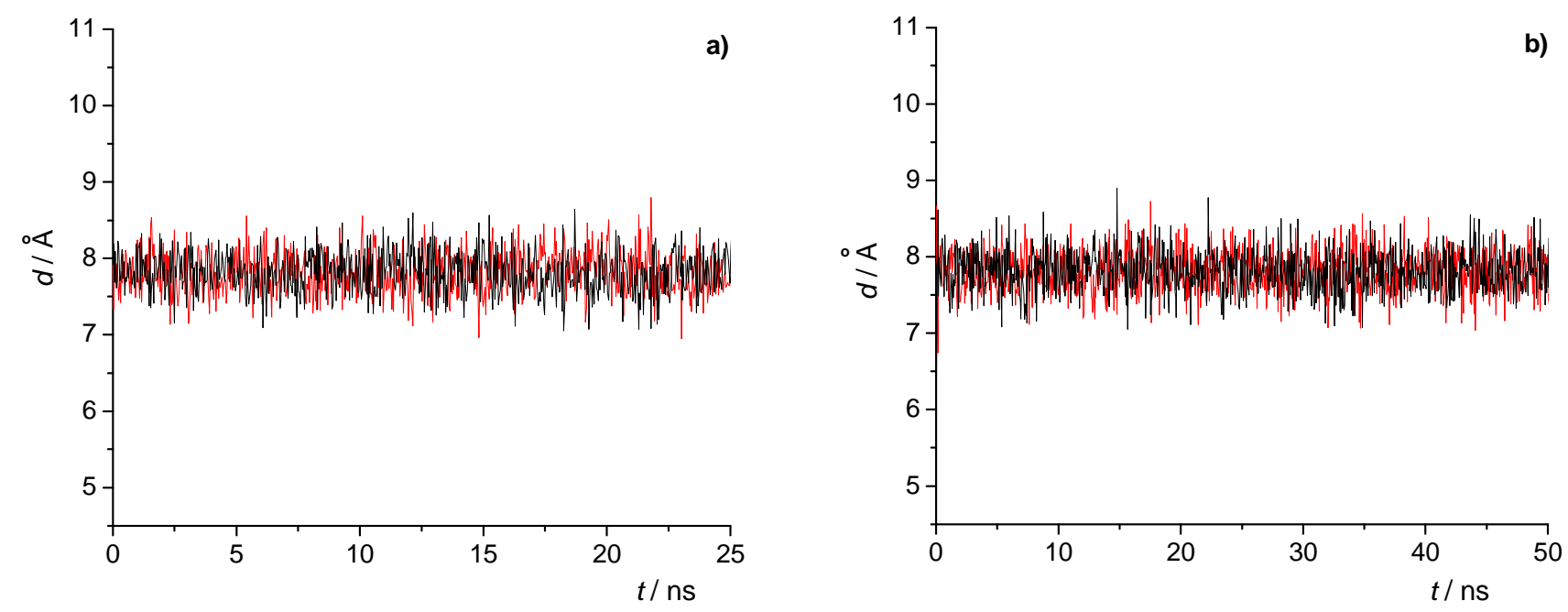

Figure S5. Distances between the opposing phenyl carbon atoms that are directly connected to the tertbutyl group during the MD simulations of a) $\mathbf{1} \cdot \mathrm{H}_{3} \mathrm{O}^{+}$and b) $2 \cdot \mathrm{H}_{3} \mathrm{O}^{+}$complexes in acetonitrile at $25{ }^{\circ} \mathrm{C}$. Due to the $1 \cdot \mathrm{MeCN} \cdot \mathrm{H}_{3} \mathrm{O}-\mathrm{Cl}$ association two simulations were performed with the duration of $25 \mathrm{~ns}$ each. Only the results of the first simulation are shown.
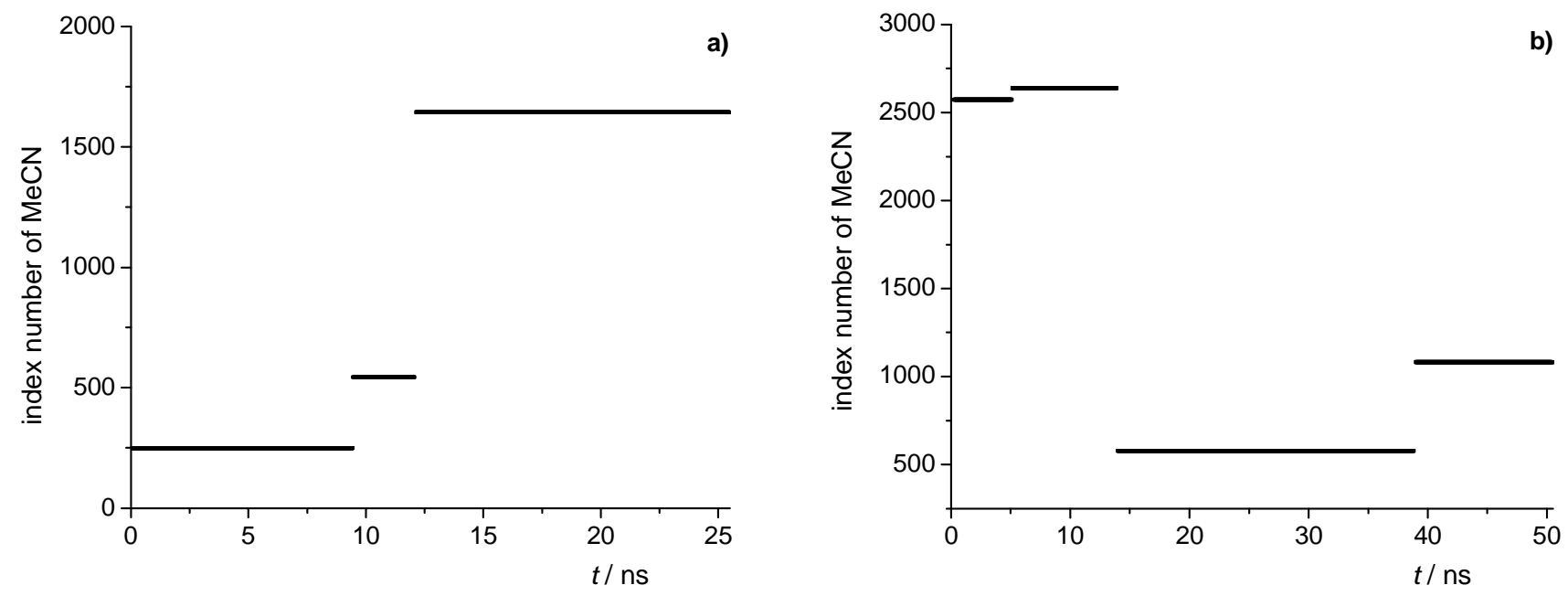

Figure S6. Index numbers of acetonitrile molecules that occupy hydrophobic cavity in a) 1 $\cdot \mathrm{MeCN} \cdot \mathrm{H}_{3} \mathrm{O}^{+}$and b) $2 \cdot \mathrm{MeCN} \cdot \mathrm{H}_{3} \mathrm{O}^{+}$during $\mathrm{MD}$ simulations in acetonitrile at $25{ }^{\circ} \mathrm{C}$. Due to $1 \cdot \mathrm{MeCN} \cdot \mathrm{NH}_{4}-\mathrm{Cl}$ association two simulations were performed with the duration of $25 \mathrm{~ns}$ each. Only the results of the first simulation are shown. 

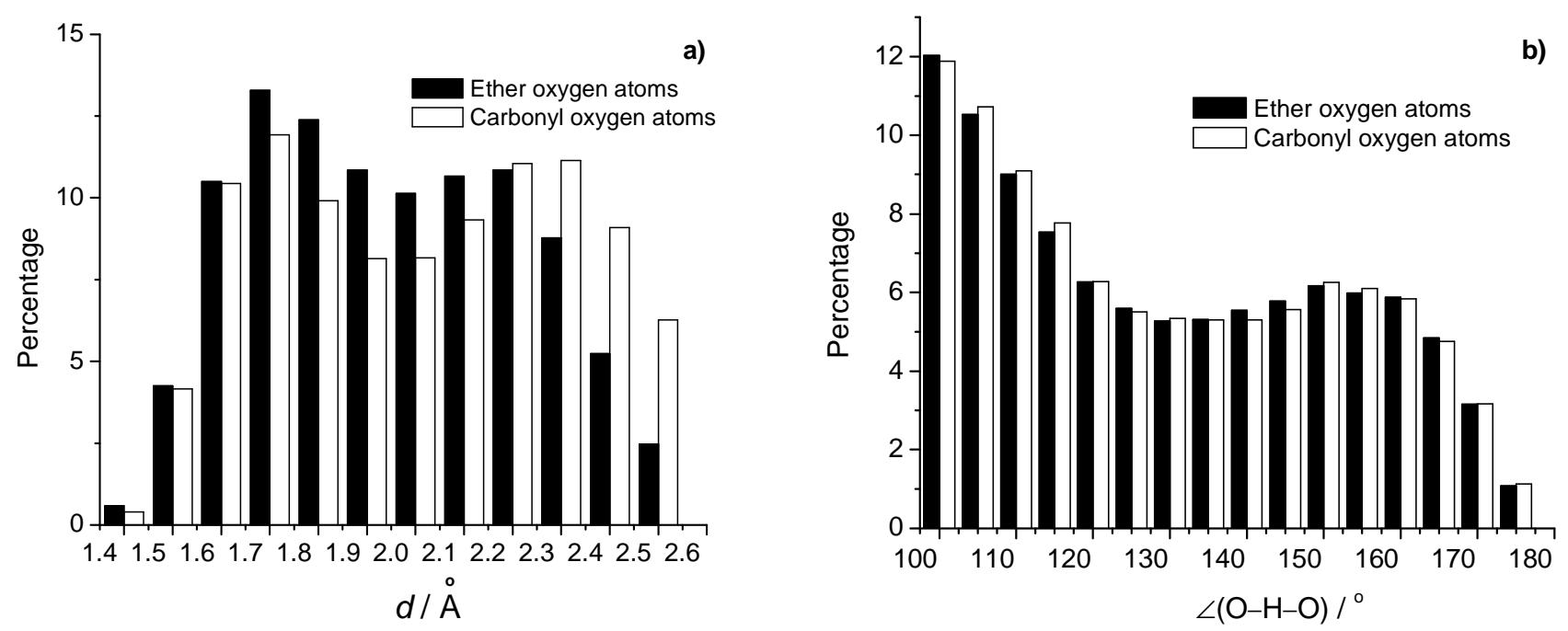

Figure S7. Hydrogen bond distribution according to a) distance between proton and hydrogen acceptor and b) angle in $\mathbf{1} \cdot \mathrm{MeCN} \cdot \mathrm{H}_{3} \mathrm{O}^{+}$complex obtained by MD simulations at $25^{\circ} \mathrm{C}$.
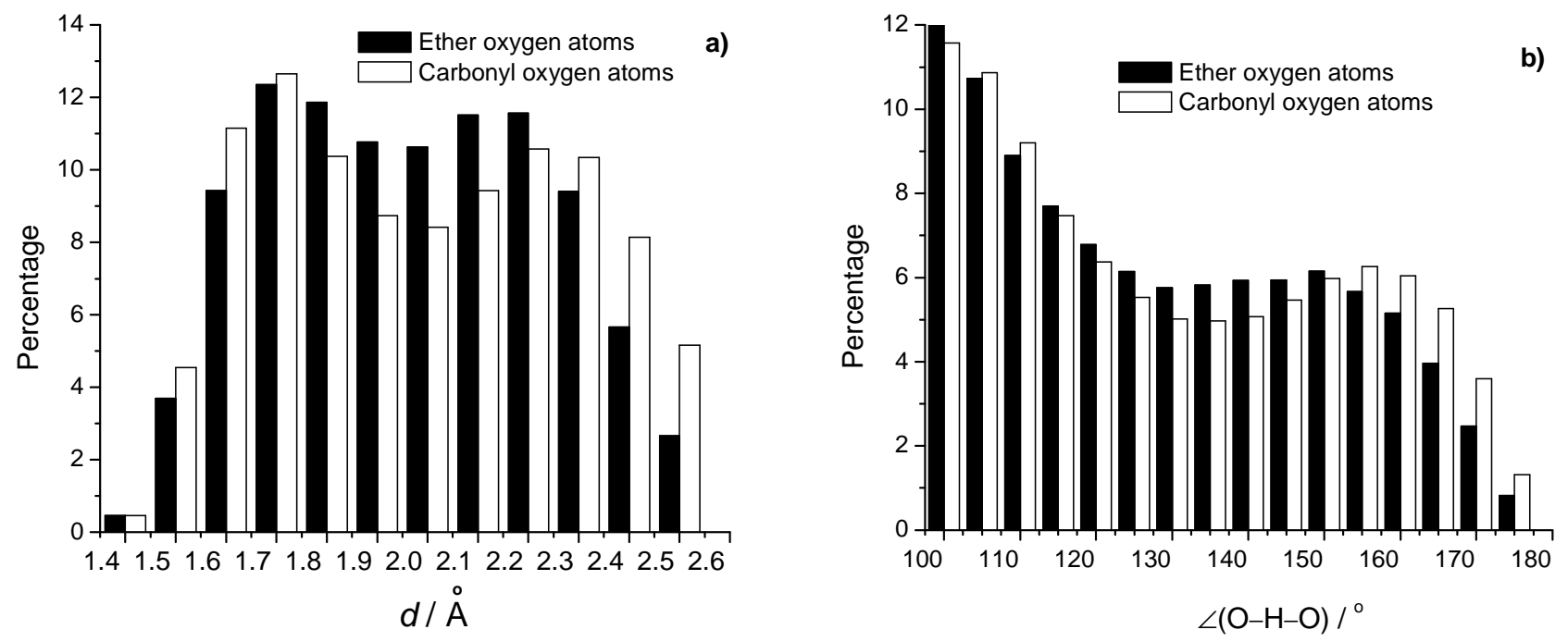

Figure S8. Hydrogen bond distribution according to a) distance between proton and hydrogen acceptor and b) angle in $\mathbf{2} \cdot \mathrm{MeCN} \cdot \mathrm{H}_{3} \mathrm{O}^{+}$complex obtained by MD simulations at $25^{\circ} \mathrm{C}$. 

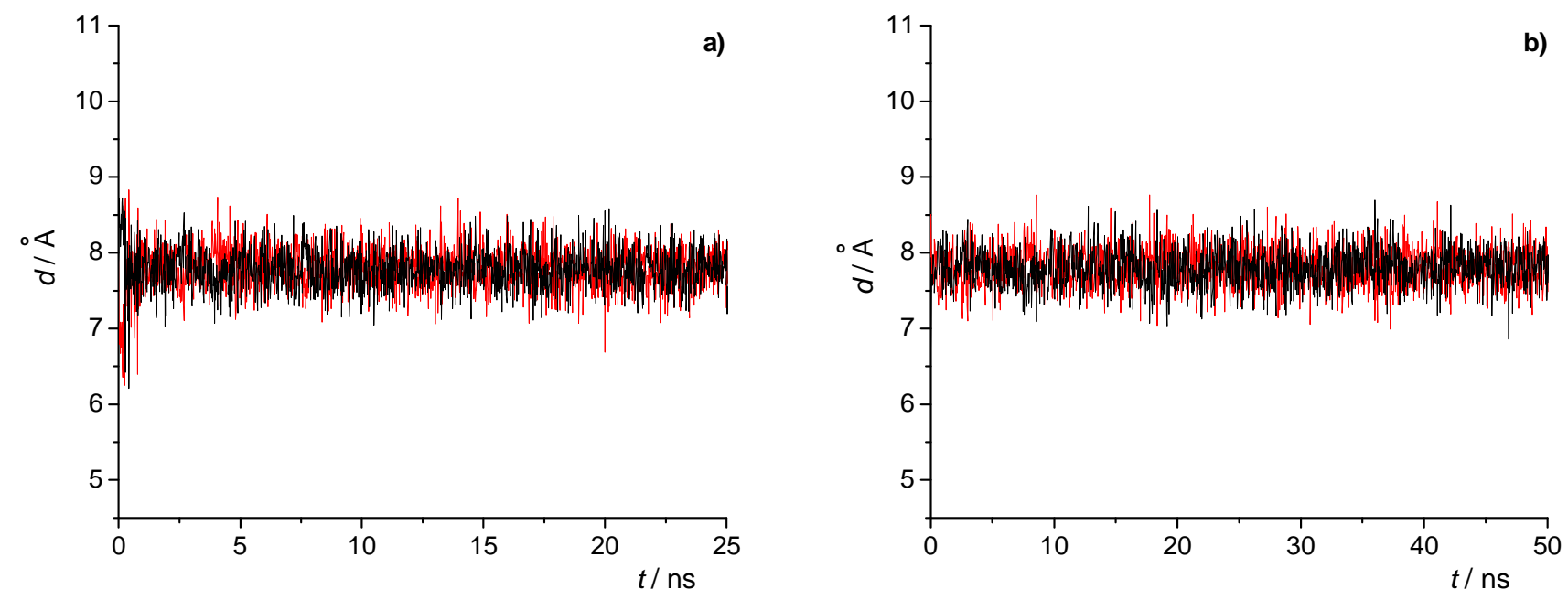

Figure S9. Distances between the opposing phenyl carbon atoms that are directly connected to the tertbutyl group during the MD simulation of a) $\mathbf{1} \cdot \mathrm{NH}_{4}{ }^{+}$and b) $\mathbf{2} \cdot \mathrm{NH}_{4}{ }^{+}$complexes in acetonitrile at $25{ }^{\circ} \mathrm{C}$. Due to $1 \cdot \mathrm{MeCN} \cdot \mathrm{NH}_{4}-\mathrm{Cl}$ association two simulations were performed with the duration of $25 \mathrm{~ns}$ each. Only the results of the first simulation are shown.
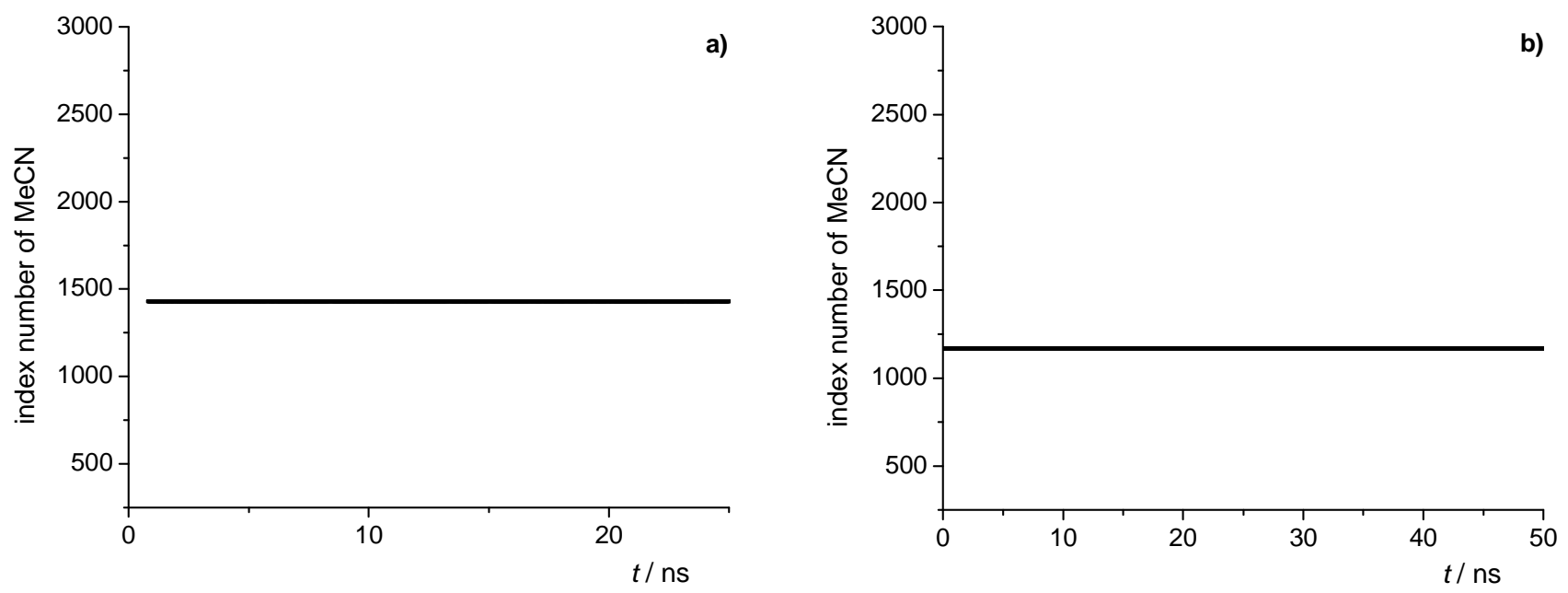

Figure S10. Index number of an acetonitrile molecule that occupies hydrophobic cavity in a) 1.MeCN$\cdot \mathrm{NH}_{4}{ }^{+}$and b) 2. $\mathrm{MeCN} \cdot \mathrm{NH}_{4}{ }^{+}$during $\mathrm{MD}$ simulations in acetonitrile at $25{ }^{\circ} \mathrm{C}$. Due to $1 \cdot \mathrm{MeCN} \cdot \mathrm{NH}_{4}-\mathrm{Cl}$ association two simulations were performed with the duration of $25 \mathrm{~ns}$ each. Only the results of the first simulation are shown. 

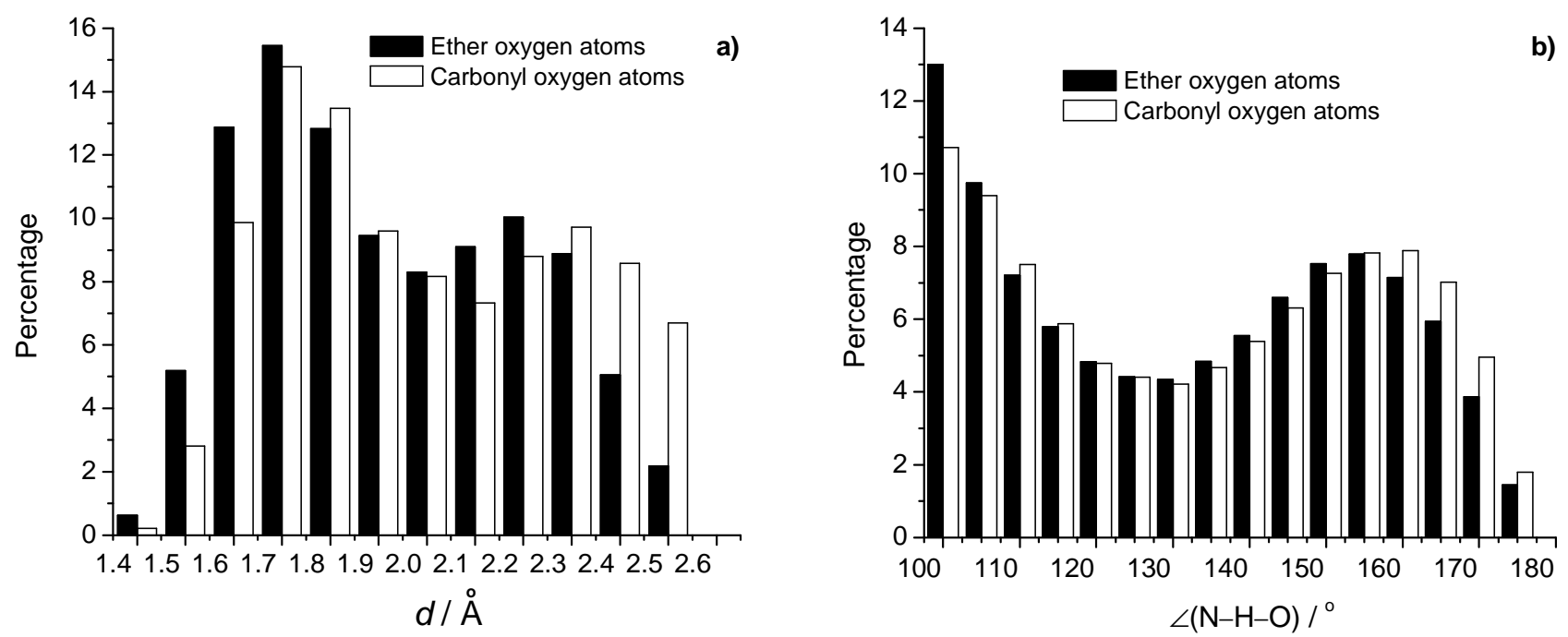

Figure S11. Hydrogen bond distribution according to a) distance between proton and hydrogen acceptor and b) angle in $\mathbf{1} \cdot \mathrm{MeCN} \cdot \mathrm{NH}_{4}{ }^{+}$complex obtained by MD simulations at $25{ }^{\circ} \mathrm{C}$.
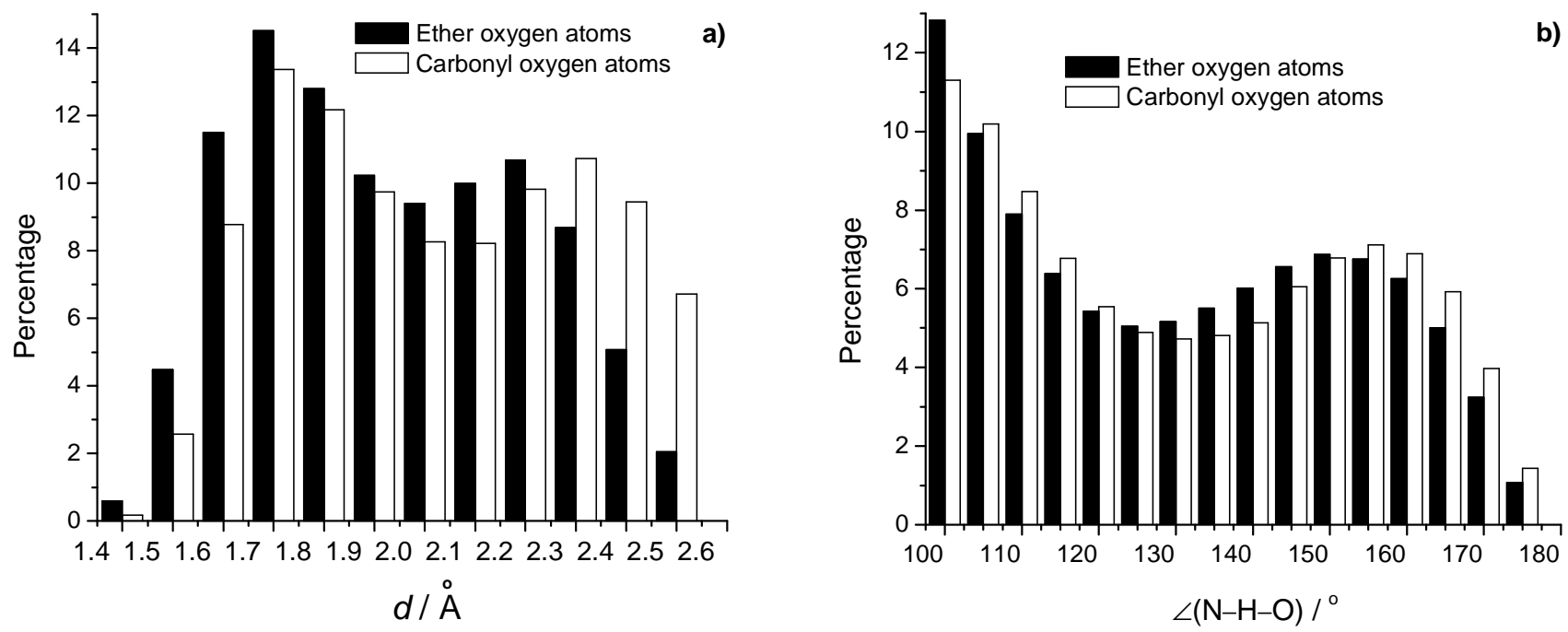

Figure S12. Hydrogen bond distribution according to a) distance between proton and hydrogen acceptor and b) angle in $\mathbf{2} \cdot \mathrm{MeCN} \cdot \mathrm{NH}_{4}{ }^{+}$complex obtained by $\mathrm{MD}$ simulations at $25^{\circ} \mathrm{C}$. 
Table S1. Dominant binding modes of oxonium cation in $\mathbf{L} \cdot \mathrm{MeCN} \cdot \mathrm{H}_{3} \mathrm{O}^{+}$complexes obtained by MD simulations.

\begin{tabular}{cccc}
\hline \multicolumn{1}{c}{$\mathbf{2}$} & \multicolumn{2}{c}{$\mathbf{2}$} \\
\hline Bonding mode & $\begin{array}{c}\text { Occurrence } \\
\text { ratio }\end{array}$ & Bonding mode & $\begin{array}{c}\text { Occurrence } \\
\text { ratio }\end{array}$ \\
\hline$\{6,4,2,1,0,2,0,0\}$ & $6.3 \%$ & $\{6,2,4,0,1,2,0,0\}$ & $6.2 \%$ \\
$\{6,4,2,0,0,1,1,0\}$ & $5.2 \%$ & $\{6,4,2,1,0,2,0,0\}$ & $5.4 \%$ \\
$\{7,5,2,1,0,1,1,0\}$ & $4.8 \%$ & $\{7,5,2,1,0,1,1,0\}$ & $4.6 \%$ \\
$\{5,4,1,1,0,1,0,0\}$ & $4.7 \%$ & $\{6,4,2,0,0,1,1,0\}$ & $4.6 \%$ \\
$\{6,3,3,1,1,1,0,0\}$ & $4.6 \%$ & $\{5,3,2,1,0,1,0,0\}$ & $3.9 \%$ \\
\hline
\end{tabular}

Table S2. Dominant binding modes of ammonium cation in $\mathbf{L} \cdot \mathrm{MeCN} \cdot \mathrm{NH}_{4}{ }^{+}$complexes obtained by MD simulations.

\begin{tabular}{cccc}
\hline \multicolumn{1}{c}{$\mathbf{2}$} & \multicolumn{2}{c}{$\mathbf{2}$} \\
\hline Bonding mode & $\begin{array}{c}\text { Occurrence } \\
\text { ratio }\end{array}$ & Bonding mode & $\begin{array}{c}\text { Occurrence } \\
\text { ratio }\end{array}$ \\
\hline$\{5,3,2,0,0,1,0,0\}$ & $7.6 \%$ & $\{7,4,3,1,0,2,0,0\}$ & $5.2 \%$ \\
$\{6,3,3,0,1,1,0,0\}$ & $6.8 \%$ & $\{5,3,2,0,0,1,0,0\}$ & $5.1 \%$ \\
$\{7,4,3,1,1,1,0,0\}$ & $6.3 \%$ & $\{6,3,3,0,0,2,0,0\}$ & $5.1 \%$ \\
$\{8,4,4,1,1,2,0,0\}$ & $5.9 \%$ & $\{8,4,4,1,1,2,0,0\}$ & $5.1 \%$ \\
$\{6,4,2,1,0,1,0,0\}$ & $4.9 \%$ & $\{6,4,2,1,0,1,0,0\}$ & $4.6 \%$ \\
\hline
\end{tabular}



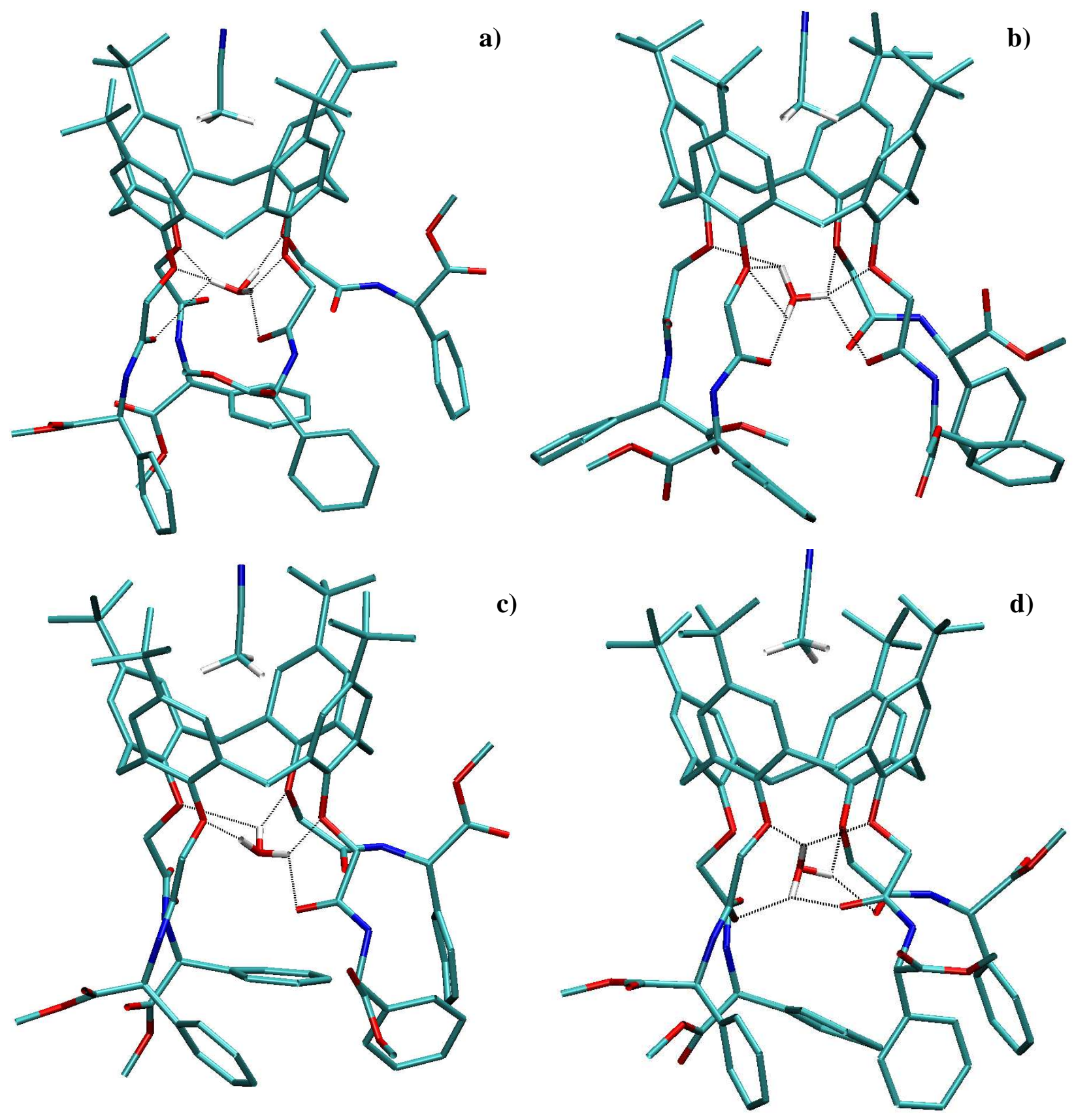

Figure S13. Molecular structures of $\mathbf{1} \cdot \mathrm{MeCN} \cdot \mathrm{H}_{3} \mathrm{O}^{+}$complex with dominant binding modes of oxonium cation obtained by MD simulations; a) $\{6,4,2,0,0,1,1,0\}$, b) $\{7,5,2,1,0,1,1,0\}$, c) $\{5,4,1,1,0$, $1,0,0\}$, d) $\{6,3,3,1,1,1,0,0\}$. 

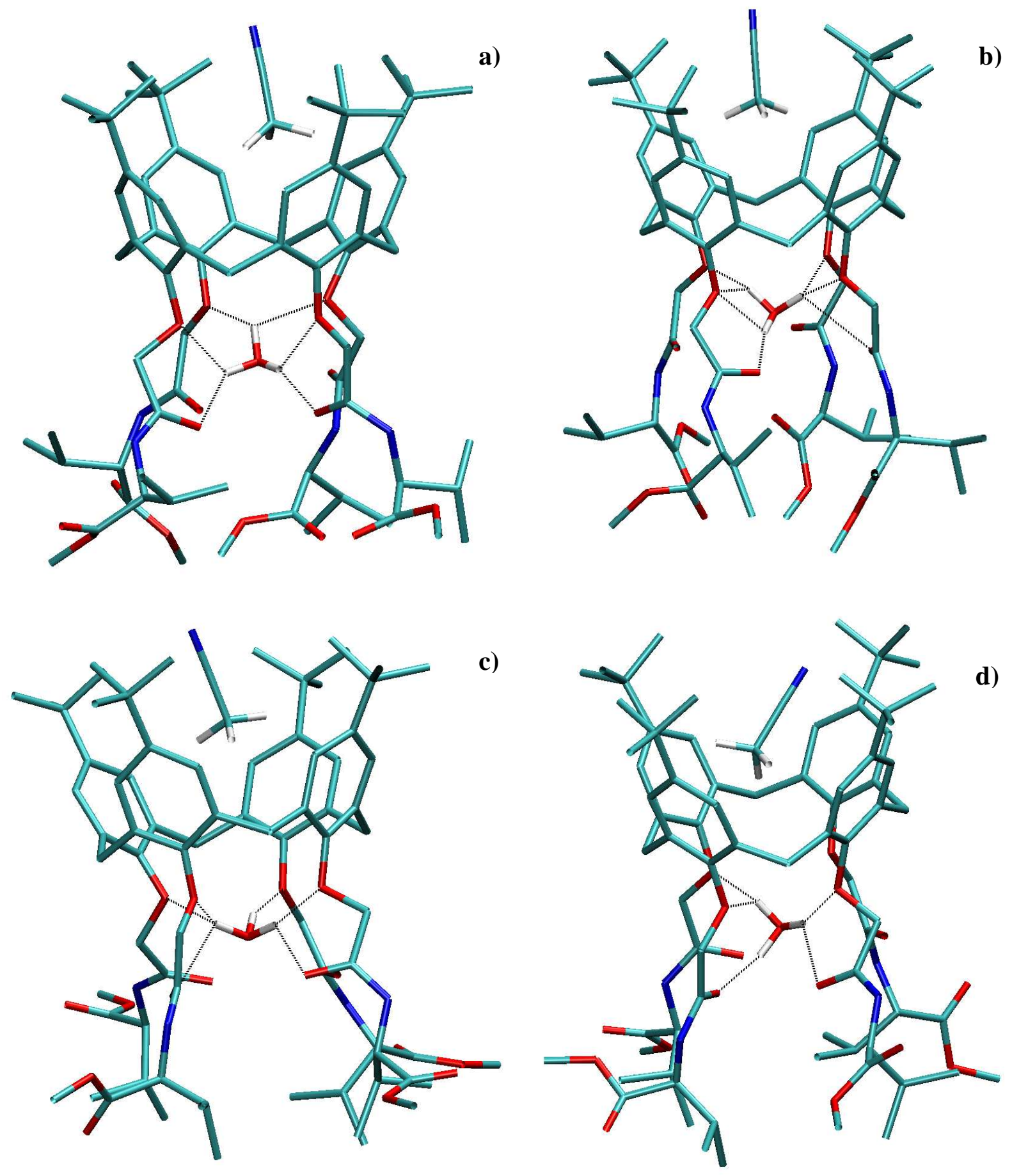

Figure S14. Molecular structures of 2 $\cdot \mathrm{MeCN} \cdot \mathrm{H}_{3} \mathrm{O}^{+}$complex with dominant binding modes of oxonium cation obtained by MD simulations; a) $\{6,4,2,1,0,2,0,0\}$, b) $\{7,5,2,1,0,1,1,0\}$, c) $\{6,4,2,0,0$, $1,1,0\}$, d) $\{5,3,2,1,0,1,0,0\}$. 

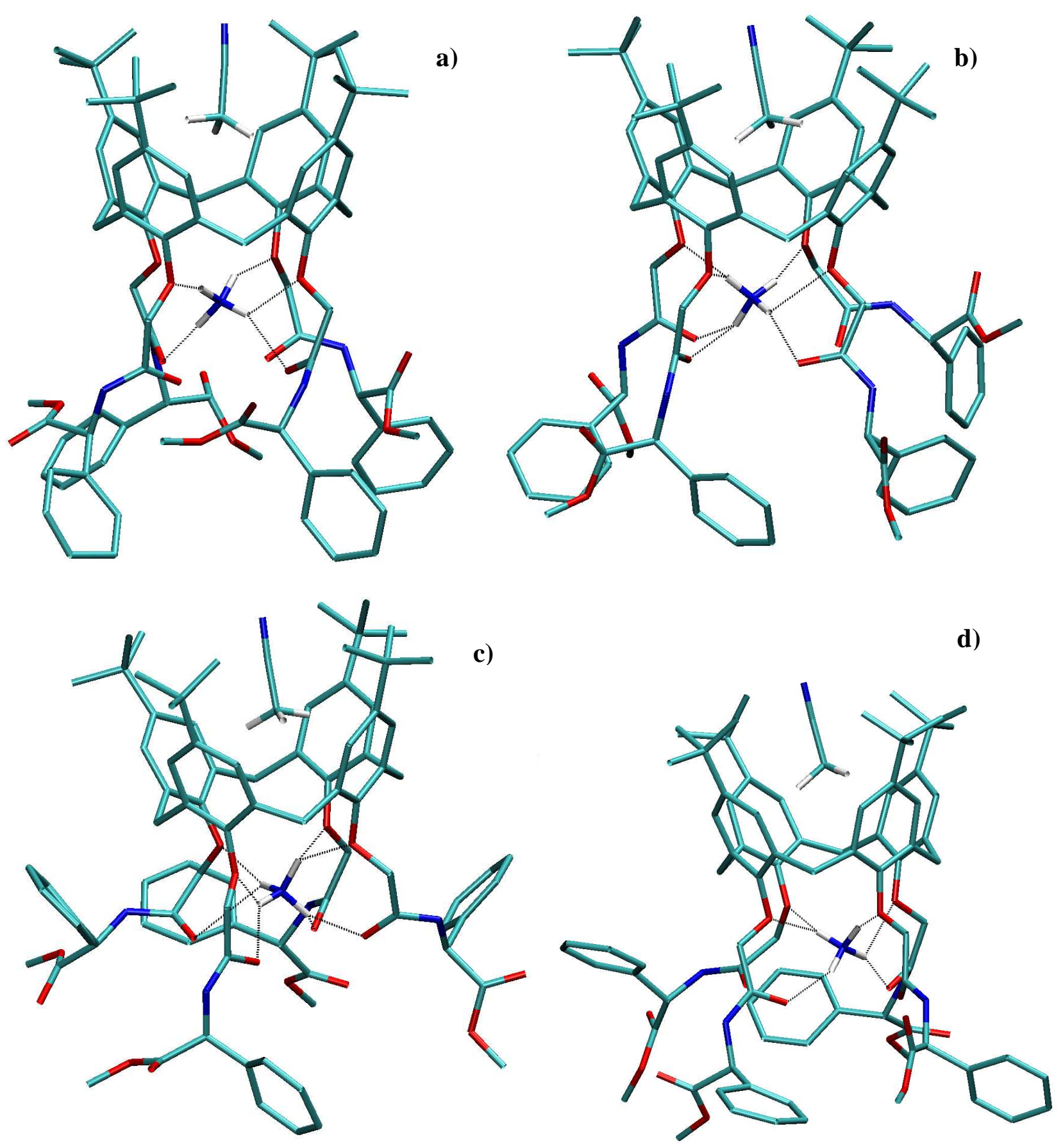

Figure S15. Molecular structures of $\mathbf{1} \cdot \mathrm{MeCN} \cdot \mathrm{NH}_{4}{ }^{+}$complex with dominant binding modes of ammonium cation obtained by MD simulations; a) $\{5,3,2,0,0,1,0,0\}$, b) $\{7,4,3,1,1,1,0,0\}$, c) $\{8,4,4,1,1,2,0,0\}$, d) $\{6,4,2,1,0,1,0,0\}$. 

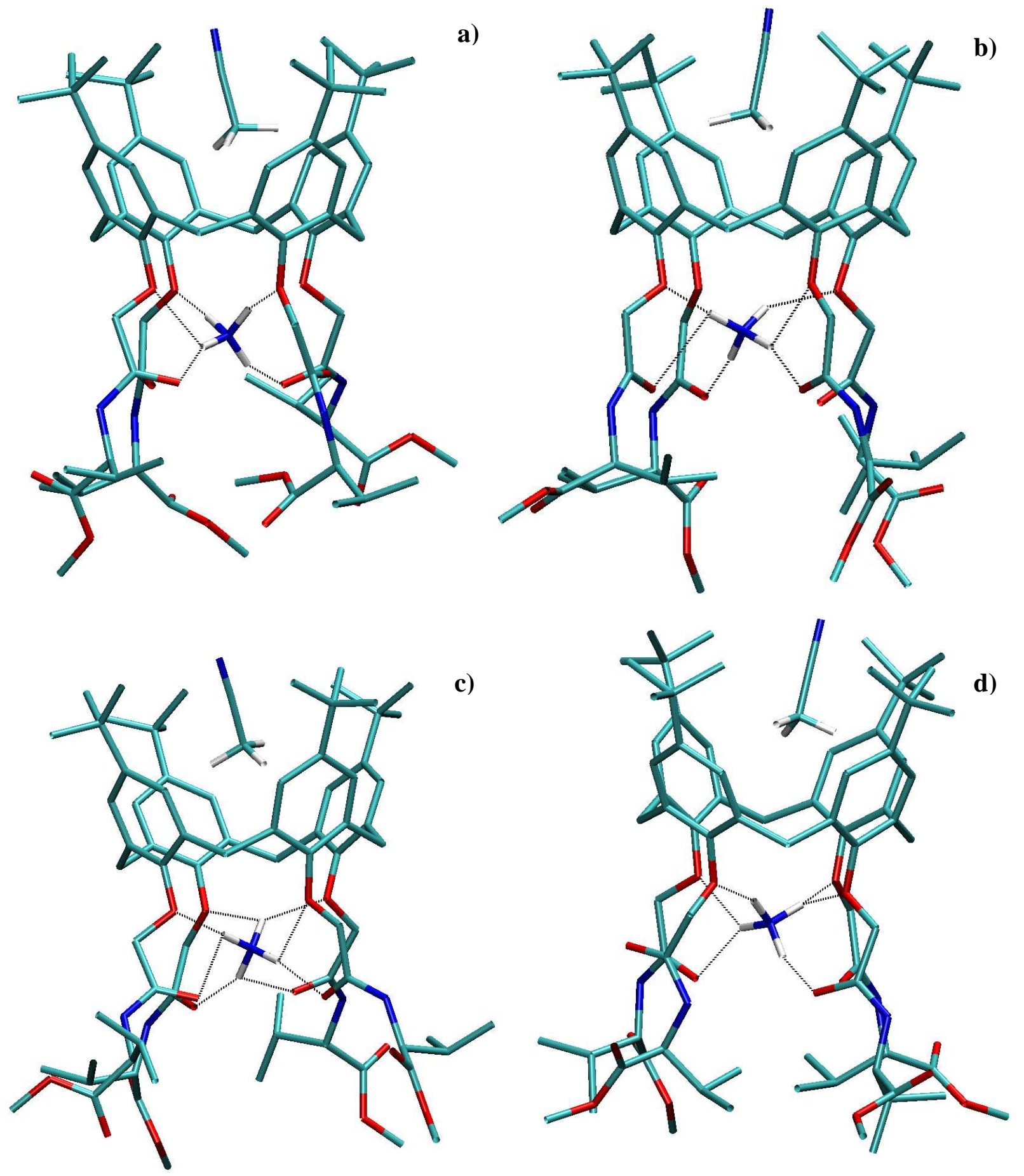

Figure S16. Molecular structures of 2.MeCN $\cdot \mathrm{NH}_{4}{ }^{+}$complex with dominant binding modes of ammonium cation obtained by MD simulations; a) $\{5,3,2,0,0,1,0,0\}$, b) $\{6,3,3,0,0,2,0,0\}$, c) $\{8,4,4,1,1,2,0,0\}$, d) $\{6,4,2,1,0,1,0,0\}$. 